NBER WORKING PAPER SERIES

\title{
CHOICE, CHANCE, AND WEALTH DISPERSION AT RETIREMENT
}

\author{
Steven F. Venti \\ David A. Wise
}

Working Paper 7521

http://www.nber.org/papers/w7521

\section{NATIONAL BUREAU OF ECONOMIC RESEARCH \\ 1050 Massachusetts Avenue \\ Cambridge, MA 02138 \\ February 2000}

This research was supported by the National Institute on Aging. We are also grateful to the Unicon Research Corporation for providing a copy of their CPS Utilities data and software. The views expressed herein are those of the authors and are not necessarily those of the National Bureau of Economic Research.

(C) 2000 by Steven F. Venti and David A. Wise. All rights reserved. Short sections of text, not to exceed two paragraphs, may be quoted without explicit permission provided that full credit, including (C) notice, is given to the source. 
Choice, Chance, and Wealth Dispersion at Retirement

Steven F. Venti and David A. Wise

NBER Working Paper No. 7521

February 2000

\section{$\underline{\text { ABSTRACT }}$}

"People earn just enough to get by" is a phrase often used to explain the low personal saving rate in the United States. The implicit presumption is that households simply do not earn enough to pay for current "needs" and to save. We show in this paper that at all levels of lifetime earnings there is an enormous dispersion in the accumulated wealthof families approaching retirement. It is not only households with low incomes that save little; a significant proportion of high income households also saves little. And, a substantial proportion of low income households save a great deal. We then consider the extent to which differences in household lifetime financial resources explain the wide dispersion in wealth, given lifetime earnings. We find that very little of this dispersion can be explained by chance differences in individual circumstances - "largely outside the control of individuals" - that might limit the resources from which saving might plausibly be made. We also consider how much of the dispersion in wealth might be accounted for by different investment choices of savers - some more risky, some less risky - given lifetime earnings. We find that investment choice is not a major determinant of the dispersion in asset accumulation. It matters about as much as chance events that limit the available resources of households with the same lifetime earnings. We conclude that the bulk of the dispersion must be attributed to differences to in the amount that households choose to save. The differences in saving choices among households with similar lifetime earnings lead to vastly different levels of asset accumulation by the time retirement age approaches.

Steven F. Venti

Department of Economics

6106 Rockefeller Center

Dartmouth College

Hanover, NH 03755

and NBER

steven.f.venti@dartmouth.edu
David A. Wise

NBER

1050 Massachusetts Avenue

Cambridge, MA 02138

dwise@nber.org 
Why do some households have substantial wealth at retirement while others have very little? Indeed, why do some households with given lifetime earnings have substantial wealth at retirement, while other households with the same lifetime earnings accumulate very little wealth? In an earlier paper [1997], we evaluated the extent to which the different wealth accumulation of households with similar lifetime earnings could be accounted for by random shocks -- like health status and inheritances -- that could reduce or increase the available resources out of which saving could be drawn. We concluded that only a small fraction of the dispersion in wealth accumulation within lifetime earnings deciles could be accounted for by random shocks and thus that most of the dispersion could be attributed to choice; some people save while young, others don't. We continue that analysis in this paper but with two additions: First we attempt to evaluate the effect of investment choice on the accumulation of assets. In particular, how much of the dispersion in wealth can be accounted for by the choice between investment in the stock market and investment in presumably less risky assets like bonds or bank saving accounts. Second, we attempt to understand the relationship between asset accumulation and individuals' assessment, just prior to retirement, of the adequacy of their saving and their saving behavior. This is very exploratory analysis and is an attempt to evaluate the usefulness of an experimental saving module administered to a sub-sample of Health and Retirement Survey (HRS) respondents.

People of course accumulate different amounts of wealth in part because they have different earnings. We essentially set that dispersion aside by considering 
persons with similar lifetime earnings. Thus the discussion here is about the dispersion of asset accumulation among persons with the same lifetime earnings. Given lifetime earnings we consider the importance of "chance" events versus the choice to save in determining asset accumulation. Over the course of a lifetime many events not directly under the control of the household may affect the accumulation of wealth. We refer to these as chance events. They may include both unfavorable shocks, such as health care costs, as well as positive shocks such as inheritances.

In contrast to such chance events that affect the resources from which saving could be drawn, we distinguish the choice of how much to save out of resources that are available. In fact, we consider two components of saving choice. One is the choice to save or not to save. The other is saving mode or investment choice. Households with similar lifetime resources may invest in different assets which earn different rates of return. We might think of three groups: non-savers, savers who invest conservatively and have low rates of return, and savers who invest in more risky assets and have higher rates of return. Persons who invest in bonds or bank savings accounts will have lower rates of return on average than those who invest in stocks.

Whether accumulated wealth is attributable to the choice to save rather than chance can have significant implications for government policy. Many policies impose ex post taxes on accumulated assets. For example, elderly Americans who have saved when young and thus have higher capital incomes when old pay higher taxes on Social Security benefits. Shoven and Wise $[1996,1997]$ show that those who save too much in pension plans in particular face very large "success" tax penalties when pension 
benefits are withdrawn. In addition, pension assets left as a bequest can be virtually confiscated through the tax system. The spend-down Medicaid provision is another example. The belief -- perhaps unstated -- that chance events determine the dispersion in wealth may weigh in favor of such taxes in the legislative voting which imposes them. If, on the other hand, the dispersion of wealth among the elderly reflects conscious lifetime spending versus saving decisions -- rather than differences in lifetime resources -- these higher taxes may be harder to justify and appear to penalize savers who spend less when they are young. From an economic perspective, if wealth accumulation is random, taxing saving has no incentive effects. On the other hand, if wealth accumulation results from conscious decisions to save versus spend, penalizing savers may have substantial incentive effects, discouraging individuals from saving for their own retirement and limiting aggregate economic growth. It is important to understand that this paper is about the dispersion in the accumulation of assets of persons with similar lifetime incomes. The issue raised here is not about progressive taxation, but rather about differences in tax imposed on persons who spend tomorrow versus today, given the same after-tax lifetime earnings.

The same issue arises with respect to return on investments. In this case, higher expected returns come at the expense of more risk when young, just as higher saving rates come at the expense of lower consumption when young. And, just as it may be harder to justify imposing higher taxes on older households who choose to consume less and save more while young, it may also be harder to justify imposing higher taxes on older households for assuming greater risk while young. In addition, of course, the Page 3 
higher taxes may discourage saving and limit economic growth. Again, the question raised here is not about progressive taxation; it is about different taxing of persons who assume risk while young versus those who don't, given the same lifetime earnings.

We begin in this paper by controlling for lifetime income as reported in individual Social Security records. Given lifetime income we examine the distribution of wealth, finding a very wide dispersion in the distribution of accumulated saving, even among families with the lowest lifetime incomes. We then show that only a small fraction of the dispersion can be explained by individual circumstances that may have limited the ability to save out of income. For persons in the same lifetime earnings decile, we do this by comparing the unconditional dispersion in wealth at retirement with the dispersion after controlling for chance events that may have affected lifetime resources out of which saving could have been drawn. Then we attempt to determine how much of the dispersion might be attributed to investment choices. Here we are limited by available data, having to rely on the allocation of assets at the time of the HRS.

Thus we conclude that the bulk of the dispersion in wealth at retirement results from the choice of some families to save while other similarly situated families choose to spend. For the most part, controlling for lifetime income, persons with little saving on the eve of retirement have simply chosen to save less and spend more over their lifetimes. It is particularly striking that some households with very low lifetime resources accumulate a great deal of wealth, and some households with very high lifetime resources accumulate little wealth. We find these saving disparities cannot be accounted for by adverse financial events such as poor health or by inheritances. 
While better control for individual circumstances that may limit resources could change somewhat the magnitudes that we obtain, we believe that the general thrust of the conclusions would not change. ${ }^{1}$

We then consider the wealth that would have been accumulated if families in our sample had followed specific saving plans throughout their working lives. This exercise shows that even families with modest lifetime incomes would have accumulated substantial wealth had they saved consistently and invested prudently over the course of their working lives.

Finally, we consider how asset accumulation, again controlling for lifetime income, is related to individual attitudes about saving and saving adequacy.

'It may be useful to view our estimates in the context of the broader literature on of saving and consumption. Our focus is on the dispersion in saving among households with similar lifetime resources. The idea is to empirically isolate the portion of the saving variance attributable to individual choice (or "tastes") once differences in lifetime earnings are accounted for. In most standard consumption models dispersion in saving arises primarily from differences in household incomes. Such models do not aim to explain the variation in wealth among families with the same lifetime incomes. Some authors, such as Attanasio, Banks, Meghir, and Weber [1995] and Venti and Wise [1990] allow saving choices to depend on household characteristics like education and marital status. Another way to account for taste variation is to estimate a distribution of rates of time preference that "fits" the variation in saving, given income. This approach has been adopted by Samwick [1996]. This approach equates taste and time preference but does not aim to distinguish choice (taste) from chance. Still another - and quite different - explanation for saving variation among households with similar resources is provided by behavioral models in which households differ in the level of discipline or self-control required to commit to a saving plan, as proposed by Shefrin and Thaier [1988]. The aim is to explain why households make different choices, but, again, not to isolate the effects of choice versus chance events.

Page 5 


\section{THE DATA}

The analysis is based on household data collected in the baseline interview of the Health and Retirement Survey (HRS). ${ }^{2}$ The household heads were age 51 to 61 in 1992 when the baseline survey was conducted. The analysis relies on the wealth of households at the time of the survey and on lifetime income, which is measured by historical earnings reported to the Social Security Administration. ${ }^{3}$ The Social Security earnings data are available for 8,257 of the 12,652 HRS respondents. Comparison of respondents for whom we do and do not have Social Security records suggests that they are very similar. Selected characteristics of the two groups are shown in Table 1. The groups have almost the same household income, the same average age, the same years of education, the same proportion are married, almost the same proportion are female. A slightly larger proportion of those for whom we have Social Security records are HRS primary respondents (64\% versus $60 \%)$.

Our analysis is based on household rather than individual respondent data, however. Historical earnings for a single-person household required only that Social Security earnings records be available for that person. But for a two-person household, it was necessary to have historical earnings for both persons in the household if both had been in the labor force for a significant length of time. The HRS obtained such

${ }^{2}$ This section and the data appendix is largely reproduced from our earlier paper [1997]. Some components of later sections also rely heavily on that paper.

${ }^{3}$ See Juster and Suzman (1995) for a discussion of the structure and content of the HRS. Mitchell, Olson and Steinmeier (1996) describe the attached Social Security earnings file. 
data for 1,625 single person households and for 2,751 two-person households, together comprising 4,376 of the 7,607 HRS households. Two additional sample adjustments were made. First, we retained households in which one or both members reported never having worked, even if the household member was missing a Social security earnings record. We assumed zero earnings for such persons. Second, we excluded from the sample all households that included any member who had zero social security earnings and reported working for any level of government for five (not necessarily consecutive) years. This latter restriction is intended to exclude households that have zero Social Security earnings due to gaps in coverage. The final sample includes 3,992 households. ${ }^{4}$

The other important data component is wealth at the time of the survey. We need a complete accounting of assets, including personal retirement assets such as IRAs and $401(\mathrm{k})$ balances, other personal financial assets, employer-provided pension assets, home equity, and assets such as real estate and business equity. In most instances the value of these assets is reported directly. For non-pension assets, the HRS survey reduces non-response considerably by adopting bracketing techniques for important wealth questions. ${ }^{5}$

\footnotetext{
${ }^{4}$ The present value of Social Security benefits are unavailable for an additional 167 households and they have been excluded in preparing Tables 3 and 4, leaving a sample of 3825 . Thus the sample is slightly smaller than was used in similar tables in Venti and Wise [1997].

${ }^{5}$ Juster and Smith [1994] and Smith [1995] provide details.
} 
In other cases asset values are not easily determined. The most important asset that is not directly reported is the value of benefits promised under employer-provided defined benefit pension plans. For persons who are retired and receiving benefits this value can be approximated by using life tables to determine the expected value of the future stream of benefits. But for persons covered by a defined benefit plan who are not retired -- and for whom the benefit is not known -- the value of future benefits can be only very imprecisely imputed. The imputation process relies on the respondent description of pension provisions and is described in detail in the appendix. The HRS also surveyed employers about the features of respondent pensions but that data is not used in this analysis.

\section{LIFETIME INCOME AND THE WEALTH OF HOUSEHOLDS}

Social Security earnings are a good measure of lifetime labor income for persons whose earning are consistently below the Social Security earnings maximum and who have been in jobs covered by the Social Security system. Historically, the Social security earnings maximum has been adjusted on an ad-hoc basis. The percentage of HRS respondents exceeding the maximum was at its highest in the early 1970's, peaking at 26.9 percent in 1971 . The percentage has been below 10 percent since 1981 and was 4.8 percent in 1991.

For persons with incomes above the limit, reported Social Security earnings can significantly underestimate actual earnings. (In addition, as explained above, some persons may report zero social security covered earnings because they were employed in sectors not covered by the Social Security system and we have excluded certain 
government employees from the sample.) Thus we do not rely directly on Social Security earnings to establish the level of lifetime earnings, but rather we use reported Social Security earnings to rank families by lifetime earnings. Then we group families into Social Security earnings deciles, which hereafter we refer to as lifetime income deciles. We believe that the ranking by Social Security earnings represents a good approximation to a ranking based on actual total earnings and thus the deciles are a good approximation to actual lifetime earnings deciles. However, the problems caused by the earnings maximum and by "zeros" may make results based on the lowest and highest deciles less reliable than results based on the other deciles.

The mean present value of lifetime Social Security earnings within each decile is shown in Table 2. To obtain lifetime Social Security income the CPI was used to convert past earnings to 1992 dollars. The means range from about $\$ 36,000$ in the lowest decile to just over $\$ 1,600,000$ in the highest decile. (Within the deciles the medians are essentially the same as the means.)

The medians of assets, including Social Security wealth, are shown in Table 3. For single persons Social Security wealth is the mortality adjusted present value of benefits. For two-person families it is the sum of the mortality adjusted present value of benefits calculated separately for each of the two. We have made no additional adjustments for joint mortality or survivorship benefits. Excluding Social Security, the median of total wealth ranges from $\$ 5,000$ for families in the lowest lifetime income decile to almost $\$ 388,000$ for families in the top lifetime income decile. Including Social Security wealth the median ranges from $\$ 33,008$ in the lowest decile to $\$ 577,107$ in the Page 9 
top decile. Many assets are held by fewer than $50 \%$ of households -- indicated by zero medians. The 5 th and 6 th income deciles span the median of lifetime income, and the median of total wealth in these income deciles is $\$ 105,166$ and $\$ 144,188$ respectively, excluding Social Security. Fewer than half of the families in these deciles have IRA or 401(k) accounts. Fewer than half have business equity or real estate. And the value of other assets is small. The median of employer-provided pension assets (excluding 401 ( $k$ ) accounts) is $\$ 6,000$ for the 5 th and $\$ 14,325$ for the 6 th lifetime income decile, not much higher than the median value of vehicles -- $\$ 6,000$ and $\$ 8,000$ respectively. The median level of financial assets is only $\$ 3,000$ and $\$ 5,000$ respectively. The largest component of the wealth of these families is home equity; the medians are $\$ 30,000$ and $\$ 35,000$ respectively.

The means of assets by lifetime income decile are shown in Table 4. Comparison of the means and medians foretells the wide dispersion in assets, even among families with similar lifetime incomes. The means are typically much higher than the medians and in some lifetime income deciles the mean of financial assets is over 10 times as large as the median.

\section{THE DISTRIBUTION OF WEALTH FOR GIVEN LIFETIME INCOME}

We discuss first the distribution of wealth within lifetime income deciles. We then consider how much of the dispersion can be accounted for investment choice and by chance shocks to resources. Personal "chance" events -- like health status or children -- that might be expected to limit the resources out of which saving might be drawn. Investment choice -- e.g. between stocks and bonds -- that may be expected to affect 
the accumulation of assets given saving out of available resources. To the extent that chance events and investment choices are correlated, however, there is of course no way to parcel out a separate effect for each of these factors. Thus we proceed in a way that indicates the maximum portion of dispersion that could be attributed to each.

\section{A. Dispersion in Asset Accumulation Given the Same Lifetime Earnings}

The dispersion in total accumulated wealth by lifetime earnings decile is shown in Figure 1a. For each earnings decile, the figure shows five quantiles: the 10th, 30th, 50th, 70th, and 90th. The median is the 50th quantile. Ten percent of families have wealth below the 10 th quantile, $30 \%$ have wealth below the 30 th quantile, and so forth. Several features of the data stand out. Perhaps not surprising, a noticeable proportion of households in the lowest lifetime income deciles have accumulated almost no wealth by the time they have attained ages 51 to 61 . Half of those in the lowest income decile have less the $\$ 5,000$ in wealth and so do $30 \%$ of those in the 2 nd decile, $20 \%$ of those in the $3 \mathrm{rd}$, and $10 \%$ of households in the 4 th income decile. But even among households with the highest lifetime incomes, some households have very limited wealth. For example, $10 \%$ of households in the 6 th income decile have less than $\$ 30,000$ in assets, $10 \%$ of those in the 9th income decile have less than $\$ 100,000$.

To address the principle question of this paper, it is the dispersion of wealth that is the most critical and here the data are striking. Even controlling for lifetime income, the range of wealth is enormous. In the 5 th lifetime income decile, the 90th quantile is 35 times as large as the 10 th quantile. The range is less extreme in higher income 
deciles but still very wide: $16,19,12,10$, and 9 in the 6 th through the 10 th lifetime income deciles respectively.

While many families with low lifetime earnings have very limited wealth -- as do some who earned the most -- the wide dispersion in accumulated wealth is evident among those with low and high lifetime earnings alike. Thus some families with the lowest lifetime earnings have accumulated noticeable wealth. For example, the 90th quantile is approximately $\$ 150,000$ for the lowest decile and is well above $\$ 200,000$ for the 2 nd and $3 r d$ deciles.

The dispersion at the highest levels of wealth accumulation is itself substantial and is presented separately in Figure 1b, which shows the 90th, 95th, and 98th quantiles by lifetime income decile. The 98th quantile is typically two and a half to three times as large as the 90th quantile. Overall there is enormous variation in wealth accumulation among households whose members had similar earnings over their lifetimes. The wide variation in wealth will not be new to many readers. Not so widely appreciated is the vast variation in wealth among households with similar lifetime earnings.

Figure 2a shows the dispersion of personal financial assets (excluding personal retirement assets such as IRA and 401(k) accounts). That most people don't save much is not new. That many of those with high incomes save so little is, however, striking. The 10 th quantile is negative or close to zero for every lifetime income decile! The same is true for the 20th quantile, with the exception of the highest earnings decile for which the 20th quantile is a paltry $\$ 6,400$. The medians range from zero for the 
lowest three deciles, to $\$ 3,000$ and $\$ 5,800$ for the 5th and 6th quantiles, to $\$ 10,000$ for the 70 th to $\$ 36,500$ for the highest income decile. Like the dispersion in total wealth the range of personal financial assets from the 10th to the 90th quantiles is extremely broad and the dispersion is even greater when the very top quantiles are considered, as in Figure $2 b$.

Almost all of the HRS respondents have had the opportunity to contribute to either an Individual Retirement Account (IRA) or a 401(k) plan. In is not surprising then, that personal retirement saving has become an important component of the wealth of some HRS households. Quantiles of personal retirement saving assets by lifetime income decile are shown in Figure 3a. Although personal retirement accounts are now an important form of personal saving, only about half of HRS households have such accounts. Most households in the highest lifetime income deciles have such accounts but households in the lowest deciles do not. Like the dispersion in personal financial saving and in total wealth, even for households with similar lifetime earnings the variation in personal retirement assets is vary large. Again, substantial variation is observed in the top quantiles as shown in Figure 3b. Although we have no way of knowing how much the IRA and 401(k) -- as well as Keogh -- limits constrained the personal retirement saving of HRS households, it is likely that many households at the top quantiles were constrained by the limits.

\section{B. Chance Events versus Saving Choice and Investment Choice}

We want to obtain an indication of how much of the dispersion in saving can be attributed to chance and how much to choice: Chance is intended to represent 
circumstances that may affect the resources available for saving -- given lifetime resources. We attribute to saving choice the dispersion that remains after accounting for chance circumstances that limit or enhance resources. We also consider how much of the dispersion in wealth can be attributed to the investment choice of savers. We proceed in two steps: First we consider how much of the dispersion in wealth can be attributed to chance events. What is not accounted for by chance events, we attribute to saving choice. Then we consider separately the effect of investment choice on the dispersion of wealth. We emphasize the effect of adjustment for chance events and investment choices on the distribution of wealth within lifetime income deciles. Thus the exposition is necessarily graphical for the most part. We do present, however, some more standard measures of reduction in dispersion when chance events and investment choices are accounted for.

In considering chance events that affect resources we do not want to control for education, ethnic group, and other attributes that may be correlates of the taste for saving. Rather we want to consider individual circumstances that may enhance or limit funds out of which saving could be drawn. We consider inheritances and gifts, health status, age, number of children, and marital status. (Age of course is not a chance event but the range of ages of HRS household heads is likely to be systematically related to asset accumulation. Children and marital status are also not truly chance events. They might more properly be thought of as choices made early in one's lifetime that may later limit resources out of which saving can be drawn. Thus we include these 
with chance events. In effect, including these household attributes tends to exaggerate the dispersion that might be attributed to truly chance events.)

That inheritances and gifts might ease the burden of saving seems clear. Poor health and associated health expenditures may increase the burden of saving. Health status may also affect lifetime earnings and thus the earnings decile of households. The question here, however, is whether given earnings, health status may affect the resources out of which households might plausibly save. Unfortunately, we have only limited indicators of health status and know little about health over a persons lifetime. Thus we use health status at the time of the survey as an imperfect control for medical circumstances. It is likely that expenses associated with children also reduce the pool of resources that could be saved. Indeed, under some circumstances children could be a substitute for saving for retirement. Finally, marital status, if only because of economies of scale, may be a determinant of resources out of which saving could plausibly be drawn.

Within each lifetime income decile, we first predict wealth with a simple specification of the form

$$
\begin{aligned}
& \text { Wealth }=\text { Constant }+ \\
& \begin{array}{l}
\beta_{1}(\text { Married })+\beta_{2}(\text { Never Married })+ \\
\beta_{3}(\text { Widowed, Divorced, or Separated })+ \\
\\
\beta_{4}(\text { No Children })+\beta_{5}(\text { Number of Children if }>0)+ \\
\\
\beta_{5}(\text { Age })+ \\
\beta_{5}(\text { Poor Health Single Person })+\beta_{7}(\text { Poor Health } 1 \text { of } 2 \text { in family })+ \\
\text { Page } 15
\end{array}
\end{aligned}
$$




$$
\begin{aligned}
& \left.\beta_{8} \text { (Poor Health } 2 \text { of } 2 \text { in family }\right)+ \\
& \beta_{9}(\text { No Inheritances })+\beta_{10}(\text { Amount of Inheritances Received }<1980)+ \\
& \beta_{11}(\text { Amount of Inheritances Received } 1980 \text { to } 1988)+ \\
& \left.\beta_{12} \text { (Amount of Inheritances Received }>1988\right)
\end{aligned}
$$

with appropriate normalizing restrictions for the indicator variables. From this equation, we obtain predicted wealth. Then within each income decile adjusted wealth is determined by

(2) $\quad$ Adjusted wealth $=($ Unadjusted wealth $)-($ Predicted Wealth $)+($ Mean of Wealth $)$

which gives distributions of adjusted and unadjusted (observed) wealth with the same means.

We follow a similar procedure to determine the effect of investment choice on wealth dispersion. Even among household that save the same proportion of earnings, accumulated wealth may differ because some households have invested savings in the stock market, for example, while other have saved through bank saving account or money market funds. The average rate of return on stock investments is much higher than the rate of return in money market funds, but the risk associated with stock investments is also higher -- or at least perceived to be higher. Other households invested primarily in housing. And, so forth. We don't know the investment choices that households made over their lifetimes. The HRS did, however, obtain information on the percent allocation of financial asset saving (excluding IRA and 401 (k) accounts)

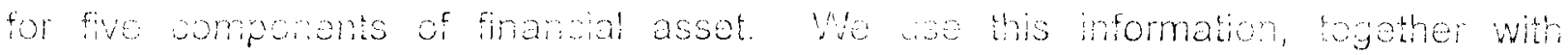


information on the proportion of wealth in housing and five other asset categories, as an indicator of the lifetime investment choices of a household. Within each lifetime income decile, we again predict wealth, but based on investment choices, with a specification of the form

$$
\begin{aligned}
& \text { Wealth }=\text { Constant }+ \\
& \beta_{1}(\% \text { Wealth in Personal Financial Assets })+ \\
& \beta_{2}(\% \text { Financial Assets in Stocks })+ \\
& \beta_{3}(\% \text { Financial Assets in Bonds })+ \\
& \beta_{4}(\% \text { Financial Assets in Money Market Accounts }) \\
& \beta_{5}(\% \text { Wealth in IRA, 401(k), and Keogh Accounts })+ \\
& \beta_{6}(\% \text { Wealth in Employer Pensions })+ \\
& \beta_{7}(\% \text { Wealth in Business Equity })+ \\
& \beta_{8}(\% \text { Wealth in Vehicles })+ \\
& \beta_{9}(\% \text { Wealth in Housing })+ \\
& \beta_{10}(\% \text { Wealth in Other Real Estate })
\end{aligned}
$$

To evaluate the dispersion in total financial assets -- including IRA, 401(k), and Keogh accounts -- that might be accounted for by investment choice, we use

$$
\begin{aligned}
& \text { Total Financial Assets }=\text { Constant }+ \\
& \beta_{1}(\% \text { Financial Assets in Stocks })+ \\
& \beta_{2}(\% \text { Financial Assets in Bonds })+ \\
& \beta_{3}(\% \text { Financial Assets in Money Market Accounts })+ \\
& \beta_{4}(\% \text { Financial Assets in Certificates of Deposit })
\end{aligned}
$$




\section{$\beta_{5}(\% \text { Financial Assets in Other Interest-Bearing Account })^{6}$}

Again, we determine adjusted total financial assets as in equation (2) above. ${ }^{7}$

We could of course adjust for both chance events and investment choice at the same time. Making separate adjustments to the same base, however, allows us to compare the effect of chance events on wealth dispersion with the effect of investment choices on dispersion. The two sets of variables may be correlated however. To the extent that they are (positively correlated), some of what is attributed to chance in the first adjustment should be attributed to investment choice instead and some of what is attributed to investment choice in the second adjustment should be attributed to chance events. Thus this procedure maximizes the adjustment attributed to each. (Standard measures of reduction in dispersion presented below suggest that the correlation between the two sets of variables is rather small, however.)

In referring to investment decisions as choice, it is important to distinguish this choice from risk -- or the chance outcomes that the choice may yield. It seems clear that part of the wealth accumulation of savers is due to choice -- conservative versus risky assets -- and part is due to chance. Chance may play a particularly prominent role

${ }^{6}$ Stocks include: shares of stock in publicly held corporations, mutual funds, and investment trusts. Bonds include: corporate, municipal, government, or foreign bonds, and bond funds Money market accounts include: checking or saving accounts and money market funds. Certificates of deposit include: certificates of deposit, government saving bonds, and treasury bills. Other interest-bearing accounts include: other saving or assets such as money owed to you by others, a valuable collection for investment purposes, an annuity, and rights in a trust or estate.

${ }^{7}$ Because the shares of total wealth, or total financial assets, can only be calculated if wealth is positive, only observations with positive wealth values are included in the estimation samples This reduces the sample from 3992 to 3584 households 
in housing investments. For example, a person who purchased a home in Boston 20 years ago likely benefitted from large capital gain. On the other hand, a person who purchased in Houston may well have lost money. We will find, however, that the wide dispersion in accumulated wealth pertains to all forms of assets; dispersion is not peculiar to housing equity. There is of course a chance aspect to financial asset accumulation as well. Given the level of risk, some savers will be winners and have large returns while others will have lower returns. But unlike a random shock to financial resources due to illness, for example, this risk and associated distribution of shocks to accumulation is chosen.

Figure 4 shows graphs of the adjusted compared to the unadjusted quantiles for each lifetime income decile. The middle bar of each panel shows unadjusted wealth quantiles. The bars behind show the quantiles adjusted for investment choice. The bars in front shows quantiles adjusted for chance events, or individual circumstances. Overall, the adjustment for individual circumstances does not have much effect on the dispersion of wealth. Thus we conclude that for the most part within decile differences in saving can be attributed to differences in the amount of income that households choose to save; some choose to save a good deal, many choose to save very little. Some of the dispersion can be attributed to investment choices. But investment choice also accounts for only a small part of the dispersion in wealth within earnings deciles. Overall, the small reduction in dispersion that can be attributed to chance events is about the same as the reduction that can be attributed to investment choices. Or, put another way: the increase in dispersion that results from differing household investment

$$
\text { Page } 19
$$


choices is approximately the same as the increase that can be attributed to chance events; both are small.

The comparison of adjusted and unadjusted distributions, however, does reveal some systematic patterns. With respect to the adjustment for chance events: First, the adjustment reduces the 95th and 98th quantiles in almost every decile and the reduction in the 98 th quantile is especially noticeable. Second, for the 5 th to the 10 th deciles, the adjustment for chance events has very little effect on all but the extreme quantiles. Modest leveling occurs within the 3rd and 4th deciles, with the 90th quantile reduced a bit and the lower quantiles raised at bit. Third, the greatest leveling occurs in the 1 st and 2 nd lifetime income deciles, in which the highest quantiles are reduced and the lowest quantiles raised. Still, in all deciles an enormous dispersion in assets remains after adjusting for the individual circumstances.

The adjustment for investment choices also reveals some systematic patterns. This adjustment has little effect on wealth dispersion in the bottom three lifetime income deciles. The greatest effects are in the upper deciles. The 98th quantile is reduced in almost every decile, especially in the upper deciles. The 95th quantile is reduced in most deciles as well, but only marginally in all but the 6 th, 8 th, and 10 th deciles. The lower quantiles tend to be raised in each earnings decile.

Finally, controlling for education and ethnic group, which are typically found to be related to saving and presumably influence the "taste" for saving, has only a very modest effect on the distributions. By way of illustration, Figure 5 shows the quantiles for the 7 th income decile when these variables are added to the list of individual Page 20 
circumstances. The principle effect of the addition of these "taste" variables is to increase a bit the lower quantiles. Nonetheless, the major dispersion remains: some people choose to save and others don't.

For comparison, more traditional measures of unconditional versus conditional variance (controlling for individual circumstances) are shown in Table 5. Starting with the unconditional variance in wealth, controlling for lifetime income decile reduces the residual standard deviation by $5.05 \%$. When lifetime income decile plus the individual chance events are controlled for (with complete interaction of income decile and attributes) the reduction is $9.08 \%$. Thus $4.03 \%(9.08 \%-5.05 \%)$ might be attributed to the chance events. When lifetime income decile plus investment choices are controlled for (again with complete interaction of income decile and investment choice) the reduction is $12.98 \%$. And, $7.93 \%(12.98 \%-5.05 \%)$ might be attributed to investment choice. Thus by this conventional measure, only a small proportion of the dispersion in wealth can be attributed to chance events. Nor can much of the dispersion be attributed to the investment choice of savers. By these measures, the effect of investment choice is somewhat greater that the effect of chance.

Controlling for income decile, chance events, and investment choice reduces the residual standard deviation by $15.32 \%$. Or, $10.27 \%(15.32 \%-5.05 \%)$ can be attributed to both chance events and investment choices together. The maximum that can be attributed to chance events, plus the maximum that can be attributed to investment choice, which is $11.96 \%(4.03 \%+7.93 \%)$, is not much greater than the reduction of $10.27 \%$ that can be attributed to both jointly. Thus there is little correlation between the 
two sets of factors; if there were no correlation, the sum of the individual reductions would equal the joint reduction.

The effect of controlling for chance events and for investment choice within income decile is shown in the second panel of Table 5. Controlling for chance events typically reduces the residual standard deviation by only a few percentage points (although as high as $23 \%$ in the second and $27 \%$ in the fourth decile). Thus within income deciles little of the dispersion can be ascribed to these individual attributes. Controlling for investment choice typically yields a larger reduction in residual variance than controlling for the chance events. In this case the reduction ranges from about $3 \%$ to $16 \%$. In the higher deciles in particular the reduction due to investment choice is around $13 \%$ on average, whereas the reduction due to chance events is around $4 \%$ on average. Although these measures are not inconsistent with the graphical information, they provide no detail on how the distribution of wealth may be affected by the individual attributes, and that is what we wish to emphasize. Thus the figures highlighted above.

We have focused above on the dispersion of total wealth. Within lifetime income deciles, wide dispersion characterizes all asset categories. Little of the dispersion can be attributed to individual household circumstances. For example, Figure 6 shows adjusted and unadjusted quantiles for personal financial assets plus IRA assets for households in the 8th lifetime income decile. Although the top adjusted quantiles are lower than the unadjusted quantiles, overall the adjustment has only a modest effect on the dispersion. 


\section{THE WEALTH THAT CONSISTENT SAVING WOULD HAVE PRODUCED}

We see that a large fraction of households on the eve of retirement have meager financial asset saving and indeed limited total wealth. We now ask what the wealth of HRS respondents might have been had they saved consistently for retirement throughout their working lives. The answer to this question can only be illustrative, because it requires a choice of saving rate out of income and a choice of rate of return. We make calculations based on several different saving rates and rate of return values. Basically, we ask what if a proportion s of earnings had been saved each year, and each year this saving had been invested in assets earning a rate of return $r^{8}$ Using a given $s$ and a given $r$, we calculate the resulting asset accumulation of our sample. There is one important limitation to this method; historical earnings are reported only up to the Social Security earnings limit, as emphasized above. Actual earnings in these deciles may be substantially higher than Social Security reported earnings.

Because of this limitation of the Social Security data, we also make calculations based on the annual March Current Population Survey (CPS) which reports earnings well above the Social Security maximum. ${ }^{9}$ We follow this procedure: (1) We identify lifetime earnings deciles, as described above, using the Social Security earnings histories of each family in the HRS. (2) Using the annual March CPS we calculate

${ }^{8}$ These calculations assume a constant rate of saving as a person ages.

${ }^{9}$ The ratio of the CPS maximum to the Social Security maximum has ranged from a low of just under 2 in 1981 to a high of over 20 in 1964. In 1991 the CPS reported earnings up to a maxımum of $\$ 200,000$; the Social Security maxımum was $\$ 53,400$ in that year 
earned income deciles by age for the years 1964-91. Using published data on median earnings prior to 1964 , we extrapolate this series back to 1955 . Thus we obtain CPS earnings histories by decile for the years 1955 to 1991 (3) To compare the Social Security with the analogous CPS data we assign each HRS household to a CPS decile according to the household Social Security earnings decile. The CPS earnings histories begin at age 25 and a given household is assumed to have been in the same decile since age 25. (4) Using this earnings profile and saving and rate of return values, we calculate accumulated wealth up to the age of the respondent at the time of the survey in 1992.

Results for several saving rates (s) and nominal investment returns ( $r$ ) are shown in Table 6. For each combination of $s$ and $r$, the first column presents results using only the Social Security earnings data. The second column shows the results of the alternative calculation based on the CPS earnings data. Calculations are made for three values of $s(5 \%, 10 \%$, and $15 \%)$ and two values of $r(6 \%$ and $12.5 \%)$. The assumed values of $s$ reflect what we believe to be "reasonable" rates of saving for households. Indeed, if saving is broadly defined to include investments in housing, businesses, pensions, and vehicles, then a rate of even $15 \%$ may be conservative. The rates of return of $6 \%$ and $12.5 \%$ are the mean annual returns for long-term corporate bonds and the Standard and Poor's index, respectively, between 1926 and 1995.

For the most part the Social Security earnings histories and the CPS constructed histories yield rather similar results, although the CPS histories are associated with 
larger wealth accumulation. The greatest differences occur at the top income deciles and are typically larger for large saving rates and rates of return. The actual assets with which these accumulations should be compared is unclear. We are inclined to compare these values to all financial assets that might be used for support in retirement -- that is, personal retirement assets, firm pension assets, and other personal financial assets. For convenience the medians of these assets are shown by lifetime income decile in the first column of Table 7 . Since housing equity is typically not used to finance retirement spending, at least not until advanced ages, it is convenient to make comparisons excluding housing equity, which is the largest asset of the majority of households. In any case, total wealth is also shown in the second column of Table 7. (The comparison should be with the actual median, and not the mean, because the same saving and rates of return are assigned to all households. In addition, within a decile, the same CPS earnings are assigned to all households.)

Saving rates of $10 \%$ would typically yield much larger assets than the median of actual total financial assets. Consider the 6th lifetime income decile, for example. Actual median total financial assets in this decile is $\$ 46,882$. With a rate of return of $6 \%$, a saving rate of $10 \%$ would have produced median assets of about $\$ 100,000$ at the time of the survey. At the average rate of return for the S\&P 500, the accumulation would have been between $\$ 250,000$ and $\$ 300,000$. The actual median of total (financial and nonfinancial) wealth in the 6 th decile is $\$ 126,082$. In all income deciles, the "as if" accumulation of financial assets is much large than the actual accumulation of financial assets. Indeed, for saving rates of $10 \%$ and the S\&P 500 rate of return the Page 25 
"as if" potential accumulation is much larger than total actual wealth. The average age of the HRS respondents is only 56 , however, so assets projected to age 65 could easily be more than double those reported in Table 6. Nonetheless these potential saving accumulations are in stark contrast with the actual saving of these families. With the illustrative lifetime saving rates and investment returns, families in all but the lowest decile would have accumulated sizable wealth by the time of the HRS survey. ${ }^{10}$

Saving rates like those used in these illustrative calculations are likely to be increasingly common with the continuing spread of $401(\mathrm{k})$ plans. For example, if current trends continue, it would not be unusual for a persons to contribute $10 \%$ of income to a 401(k) and invest in an S\&P 500 index mutual fund. It is easy to see that consistent lifetime saving, perhaps through a 401(k) plan, could yield large asset accumulations for a very substantial fraction of households. This prospect is considered in some detail by Poterba, Venti, and Wise [1997].

\section{SELF-ASSESSED SAVING ADEQUACY, ATTITUDES TOWARD SAVING, AND ASSET ACCUMULATION}

Two experimental saving modules were administered to sub-samples of respondents in the third wave of the HRS. Each of the two modules was given to $10 \%$ of respondents, although not the same respondents. The goal of these experimental modules was to explore possibilities for discovering more about the attributes of persons who save compared to those who don't, with the ultimate goal of

\footnotetext{
${ }^{10}$ in the CPS data families in the lowest SS earnings decile are assumed to have been in the lowest earnings decile in all vears. Thus in most years these families are assumed to be zero earners.
}

Page 26 
understanding more about what determines saving behavior. In addition, the modules asked respondents about the adequacy of their retirement saving. We explore here the relationship between responses to the saving module questions and realized saving as described in section III.

The experimental module sample sizes are small. There are 460 observations in one of the two that we use and 390 in the other. About half of these observations are not used here, primarily because of missing Social Security records. ${ }^{11}$ Thus, we need a convenient way to measure the realized saving of each household in such a way that we can avoid separate analyses by lifetime earnings decile. The $10 \%$ samples do not yield large enough sample sizes to do this reliably. Thus we calculate a variable $Q$, which in this paper is the within-decile wealth quantile of each household. For example, if a household has wealth just at the median of other households within an earnings decile, the $Q$ assigned to this household is 50 . This measure is independent of earnings decile. It tells us how the wealth of each household compares to the wealth of other households with similar lifetime earnings. Thus two households in different lifetime earnings deciles but with the same $Q$ can be thought of as having the similar "taste" for saving. Households with different $Q$ values have different taste for saving.

We first consider the relationship between self-assessed adequacy of saving and Q. Table 8 shows respondent answers to several questions, together with their $\mathrm{Q}$ values. The first question asked wether the respondent's saving over the past 20 or 30 1.

"There is no reason to believe that these exclusions are not random, as shown in Table Page 27 
years was about right, too much, or too little. Almost three-fourths of the respondents said too little. About a quarter said about right. Virtually no one said too much. Those who said about right had an average $Q$ with respect to total wealth of 61 -- meaning that on average they were at the 61 st percentile of the total wealth distribution within their lifetime earnings decile. Those who responded too little had an average $Q$ of 46 . Thus a large fraction of respondents say they saved too little and they have $Q$ values substantially lower than those who say they saved enough. (To judge the difference in wealth of these two groups, the 61st quantile is typically about one and one-half to two times as large as the 46th quantile.) The last column of the table reports $Q$ values based on total financial assets, including IRAs and $401(\mathrm{k})$ balances. Comparisons based on financial assets typically parallel those based on total wealth, as they do in this case. Apparently consistent with responses to the first question, the next question reveals that about two-thirds of respondents said they would save more if they could do it again and about a third said they would save about the same.

The third question asked whether, including Social Security and pensions, the respondent would have enough saving to maintain "your standard of living" after retirement, $67 \%$ said yes and only $33 \%$ said no. Thus many households who say they did not save enough also say they will be able to maintain their standard of living in retirement. However, of those who said yes the average Q was 58; it was only 46 for those who said no. Apparently a substantial portion of respondents with relatively low Q say they will be able to maintain their standard of living (e.g. if those who said yes have $Q$ values between 16 and 100 the average would be 58 ), even though many of 
these also say they have saved too little. Of those who answered yes, about $75 \%$ said they could maintain the same standard.

From the experimental modules, can we learn anything about the relationship between individual attributes and realized asset accumulation? Apparently we can. Table 9 shows responses to a series of questions about individual behavior or attitudes together with average $Q$ values. It is clear that there is a strong relationship between the age at which respondents started saving for retirement and Q: those who started saving before 25 have an average $Q$ of 63 . Q declines consistently with postponement of retirement saving; respondents who never started to save for retirement have an average $Q$ of 37 .

It also appears that having a target or planned level of saving makes a difference. Those who said they had such a target have an average $Q$ of 56 , while those who had no target have an average $Q$ of 48 . Most of those who had a target also said they had a plan for achieving that target and most also said the plan included trying to save something out of each paycheck. If the plan included saving out of each paycheck the average $Q$ was 59 ; if not the average $Q$ was 36 . A question on a different module asked simply: "Over the past years, did you have a plan for retirement saving?" In response to this question, $47 \%$ said yes and they had an average $Q$ of $60 ; 53 \%$ said no and they had an average $Q$ of 48 . The implication is that having a plan to save for retirement contributes to asset accumulation. And, perhaps trying to save something out of each paycheck was the key to greater asset accumulation. 
The questions asking how respondents would characterize themselves seem only weakly related to asset accumulation. Those who said they could "never get caught up on my bills" or that they could "never stick to a saving plan" accumulated about the same as those who said these attributes did not describe them. Given the promise of Social Security benefits, it may be that many households rationally choose to save little, in particular those with low lifetime earnings, for whom the Social Security replacement rate is relatively high. But only about a quarter of respondents said they "thought Social Security or employer pensions would take care of my retirement income." And the average $Q$ of this group was 50 , not much lower than the average of 58 for those who said this view did not characterize them. The difference in $Q$ values for total financial assets are greater -- 46 versus 59 . Thus the responses suggest some relationship between expected Social Security and employer pension benefits and other saving, but certainly not enough to explain the very low asset accumulation of a large fraction of respondents. Even for respondents in the lower lifetime earnings deciles there appears to be little relationship between the anticipated importance of Social Security and $Q$ values for total wealth, as shown in the tabulation below. The responses do suggest, however, that respondents in the lower earnings deciles who anticipated that Social Security and pensions would be important have lower total financial asset $Q$ values than those who thought Social Security and pensions would be less important. 


\begin{tabular}{|lccc|}
\hline Response & \multicolumn{3}{c|}{ Earnings Decile } \\
& $\begin{array}{l}\text { 1st-3rd } \\
\text { 4th-7th }\end{array}$ & 8th-10th \\
0 to 3 & 59 & 63 & 56 \\
4 to 6 & 61 & 56 & 42 \\
7 to 10 & 60 & 45 & 52 \\
& Total Wealth Q \\
0 to 3 & 56 & 65 & 57 \\
4 to 6 & 59 & 54 & 45 \\
7 to 10 & 36 & 42 & 51 \\
\hline
\end{tabular}

This sort of finding might be contrasted with results based on theoretical models of economic behavior. Hubbard, Skinner, and Zeldes [1995], for example, use a lifecycle model of saving, that accounts for precautionary motives for saving, to simulate the dispersion in wealth of low-income households in particular. They show how under their model social insurance programs with asset-based means testing can discourage saving by households with low expected lifetime incomes.

Could limited financial literacy be one reason some people don't save. To explore this possibility the survey posed a question intended to test respondents understanding of compound interest. Respondents were asked what they thought would be the current value of $\$ 10,000$ saved at age 25 if the interest rate had been $5 \%$. Depending on the age of the respondent in 1992, the appropriate answer is between $\$ 40,000$ and $\$ 70,000$. Although a small proportion of respondents give answers below 
this range, more than half give answers well above this range. About a third are within the range. However, there seems to be no clear relationship to asset accumulation.

Finally, the saving modules include a series of questions about anticipated sources of retirement income. Respondents who thought Social Security benefits would be important have an average $Q$ of 47 ; those who thought Social Security benefits would be unimportant have an average $Q$ of 65 . The question discussed above, which asked whether "social security or employer pensions would take care of my retirement income" described "your" saving behavior, seemed related only to the saving of persons with low lifetime earnings. The response to this question suggests a more general correspondence between reliance on Social Security and saving. Greater anticipated importance of IRAs and 401(k) would almost surely be associated with greater wealth because they are included in total wealth and in total financial assets. Employer-provided pensions, however, are not included in total financial assets. Keeping in mind that $Q$ controls for earnings decile, it is rather striking to find that respondents who anticipate that pensions will be important in retirement have an average $Q$ of 55 , while those who say pensions will be unimportant have an average $Q$ of only 44. Such evidence may perhaps support the view that saving has a multiplier effect: saving in one way induces saving in other forms as well. Having an employer pension, for example, may be accompanied by information about financial needs in retirement.

In addition to the questions discussed above, the experimental modules asked respondents whether, in thinking about their financial futures, they were concerned 
about several events: job loss, financial market collapse, and health care costs. The results are presented in Table 10. Few were very concerned about job loss or financial market collapse. But a large fraction of respondents were concerned about potential health care costs. And, the concern with health care costs is weakly related to $Q$. Job loss on the other hand is a much greater concern for those with low $Q$ than for those with higher $Q$ : those who say they aren't concerned with job loss have an average $Q$ of 55 , while those who are very concerned have an average $Q$ of only 39 . Concern with financial market collapse is not strongly related to $Q$, although those who are more concerned about this event have somewhat higher $Q$ values than those who are unconcerned, perhaps as should be expected.

\section{CONCLUSIONS AND DISCUSSION}

In 1953, Milton Friedman wrote a paper he called "Choice, Chance, and the Personal Distribution of Income." In this paper he says:

Differences among individuals or families in the amount of income received are generally regarded as reflecting either circumstances largely outside the control of the individuals concerned, such as unavoidable chance occurences and differences in natural endowment and inherited wealth ... The way that individual choice can affect the distribtion of income has been less frequently noticed. The alternatives open to an individual differ, among other respects, in the propability distribution of income they promise. Hence his choice among them depends in part on his taste for risk... The foregoing analysis is exceedingly tentative ... Yet $I$ think it goes far enough to demonstrate that one cannot rule out the possibility that a large part of the existiing inequality of wealth can be regarded as produced by men to satisfy their tastes and preferences.

Now, over 40 years later: "People earn just enough to get by" is a phrase often

used to explain the low personal saving rate in the United States. The implicit

$$
\text { Page } 33
$$


presumption is that households simply do not earn enough to pay for current "needs" and to save. Yet in other developed countries the saving rate at all income levels is much higher than in the United States. Even in Canada -- in many respects similar to the United States - the personal saving rate is almost twice as high as in the United States. Such international comparisons alone suggest that saving depends on much more than lifetime earnings.

We show in this paper that at all levels of lifetime earnings there is an enormous dispersion in the accumulated wealth of families approaching retirement. In the United States it is not only households with low incomes that save little. A significant proportion of high income households also save very little. And, not all low-income households are non-savers. Indeed a substantial proportion of low income households save a great deal. We then consider the extent to which differences in household lifetime financial resources explain the wide dispersion in wealth, given lifetime earnings. We find that very little of this dispersion can be explained by chance differences in individual circumstances -- "largely outside the control of individuals" that might limit the resources from which saving might plausibly be made. Thus we conclude that the bulk of the dispersion must be attributed to differences in the amount that households choose to save. Choices vary enormously across households. Some choose to save more and spend less over their working lives while others choose to save little and spend more while working. Wide dispersion in saving is evident at all levels of lifetime earnings, from the lowest to the highest. The differences in saving 
choices among households with similar lifetime earnings lead to vastly different levels of asset accumulation by the time retirement age approaches.

Perhaps more closely related to the choice of risk that Friedman emphasized, we also considered how much of the dispersion in wealth might be accounted for by different investment choices of savers -- some more risky, some less risky -- again, given lifetime earnings. We find that investment choice matters but it is not a major determinant of the dispersion in asset accumulation. It matters about as much as chance events that limit the available resources of households with the same lifetime earnings. Thus although investment choices make a difference, the overwhelming determinant of the accumulation of wealth at retirement is simply the choice to save.

As a benchmark, we also considered the assets that the HRS respondents would have accumulated had they saved given amounts over their working lives and had earned given returns on their saving. Saving $10 \%$ of earnings and earning the average annual S\&P 500 return (which has been 12.2\% since 1926) would have led to accumulated assets much much greater than the typical financial assets of HRS households at the time of the survey.

Perhaps based on the presumption -- contrary to Friedman's conjecture -- that differences in wealth can be attributed more to differences across households in adverse circumstances that limit saving, rather than explicit individual choices, government policy often penalizes persons who have saved over their lifetimes. For example, persons with the same lifetime earnings will face very different tax rates on Social Security benefits: those who saved will pay higher taxes while those who didn't Page 35 
will pay lower taxes. Shoven and Wise $[1996,1997]$ show that persons who save too much through personal or employer-provided pensions face enormous tax penalties when they use these accumulated assets for retirement support. The evidence that differences in retirement wealth is do largely to saving choice while younger brings into question this tendency in tax policy. Although the distribution of the tax burden will inevitably be based on many factors, most observers believe that the extent to which older persons with more assets are taxed more should depend in part on how they acquired the assets. Chance accumulation may weigh on the side of heavier taxes on those who have accumulated. On the other hand, accumulation by choosing to consume less when young, while others chose to consume more when young, weights against heavier taxes on those who accumulate assets for retirement. As emphasized at the outset, this paper is about the dispersion in the accumulation of assets of persons with similar lifetime earnings. The issue raised here is not about progressive income taxation, but rather -- given the same after-tax earnings -- about differences in the tax imposed on persons who save today in order to spend more tomorrow, versus those who spend all today. Our analysis suggests that a very large proportion of the variation in the wealth of older households can be attributed to household saving choices while younger rather than chance events that may have limited the resources available for saving. To the extent that most asset accumulation is due to choice rather than chance, our results also suggest that ex ante taxing of saving may have more serious consequences for saving than may previouly have been thought. 
Finally, we explored the relationship between household saving and information about household saving that was obtained through two experimental saving modules administered in the third wave of the HRS. In general, the experimental module responses were consistent with household realized asset accumulation. About three fourths of respondents said they had saved too little over the past 20 or 30 years and we found a strong relationship between our $Q$ value -- a household's percentile level of assets, given lifetime earnings -- and whether respondents thought they had saved enough. The accumulation of retirement assets is very strongly related to age at which persons began to save for retirement. In addition, persons who accumulated more retirement assets tended to have a saving target or plan and the plan typically included saving a portion of each paycheck. Those who accumulated little were more likely to say thay they just couldn't get caught up on their bills or that they had a hard time sticking to a saving plan. Low saving rates seem to be only weakly related to an expectation that Social Security or employer pension plans would take care of retirement income, even among households with low lifetime earnings. The potential cost of health care is an important concern of a large fraction of households and this concern appears to be unrelated to asset accumulation. On the other hand, there appears to be relatively little concern about job loss, supporting children or parents, or financial market collapse. The results from the HRS experimental saving modules suggests to us that this type of information collection might fruitfully be pursued in more depth. 


\section{Appendix}

\section{A. The Sample}

The analysis is based on the first wave of the Health and Retirement Survey (HRS) which sampled a families with heads aged age 51 to 61 in 1992 . This wave of the HRS includes 12,652 respondents in 7,702 households. For two reasons our analysis was based on only 3,992 households.

First, in 379 married or partnered households one of the respondents did not respond to the survey. Because the pension wealth of both members is a critical component of the analysis, we have deleted these households from the sample.

Second, the analysis relies heavily on lifetime income as measured by Social Security earnings records. These records are available for only 8,257 of the 12,652 HRS respondents. The analysis is based on household rather than individual respondent data. Historical earnings for a single-person household required only that Social Security earnings records be available for that person. But for a two-person household, it was necessary to have historical earnings for both persons in the household if both had been in the labor force for a significant length of time. The HRS obtained such data for 1,625 single person households and for 2,751 two-person households, together comprising 4,376 of the 7,607 HRS households .

Two related sample adjustments were made. First, we retained households in which one or both members reported never having worked, even if the household member was missing a Social Security earnings record. We assumed zero earnings for such persons. Second, we excluded from the sample all households that included any member who had zero social security earnings and reported working for any level of government for five (not necessarily consecutive) years. This latter restriction is intended to exclude households that have zero Social Security earnings due to gaps in Social Security coverage. The final sample includes 3,992 households.

B. Wealth

Total wealth is comprised of the following broad categories: 
Financial Assets: stocks, mutual funds, investment trusts, checking or saving account balances, money market funds, CDS, government saving bonds, treasury bills, bonds, bond funds, and other savings or assets, less unsecured debt.

Personal Retirement Assets: IRA, Keogh, and 401(k) balances.

Firm Pension Assets: defined contribution plan balances (other than $401(k)$ ) and the present value of promised defined benefit plan benefits. (See below for details.)

\section{Net Vehicle Equity}

\section{Net Business Equity}

Real Estate: real estate other than main home, net of debt

Home Equity: value of primary residence less outstanding balances on all mortgages, home equity loans, and lines of credit used.

\section{Pension Wealth}

\section{C.1. Imputation of Key Missing Data}

It is particularly difficult to produce a measure of pension wealth for this sample. ${ }^{12}$ Many respondents were missing key pieces of data needed to construct pension wealth. For some types of pensions less than half of the respondents provided data complete enough to directly calculate pension wealth. Here is a brief overview of the procedures used to impute these missing data:

In the HRS, the information required to construct pension wealth comes from three sources: the pension on the current job for persons still working, the pension on the last job for persons no longer working, and pension income by source for persons receiving benefits. ${ }^{13}$

All currently employed workers were asked if they were "included in" a pension plan "through your work" (if self-employed), or if they were "included" in a pension plan

${ }^{12}$ Our estimates of pension wealth are based on the respondent's report of the provisions of employer sponsored pension plans. The HRS also conducted a survey of employers. Information from this latter survey is not used in this analysis.

${ }^{13}$ There is also some information on pensions associated with previous jobs (other than the last job), but we judged these data to be too incomplete to use at this time. 
"sponsored by your employer or union" (if not self-employed). Each respondent could list up to three plans. About 76 percent of the respondents listed a single plan, 21 percent listed two plans, and the remaining 3 percent of the respondents listed three plans. Respondents were most likely to cite a defined benefit (DB) plan as their first plan. Of the first plans reported, 61 percent were DB and 34 percent were defined contribution (DC) plans. Of the second plans reported, only 16 percent were DB; 81 percent were DC. Most of the third plans reported were DC.

For each of the three plans, if the reported plan type was DB, 'both' or 'don't know', then the respondent was first asked the expected age of retirement, then asked to give an estimate of the pension benefit at retirement. The benefit could be expressed as a percentage of final salary or as an amount $(\$)$ per unit of time (month, quarter, year, etc.) or as a lump-sum at retirement. Most respondents (44 percent) gave an amount per unit of time and we have converted these to annual pension benefits. For those providing a percent of final salary (15 percent) we have also computed an annual pension benefit using an assumed (see below) annual rate of growth of earnings until the expected date of retirement. Still, there is much data missing; the remaining 41 percent of the plans require imputation. To impute pension benefits we first divide the sample by the number of plans (three could be listed), type of response (DB, DC, or both), and ten wage and salary income deciles. We then used a hotdeck imputation procedure using these ninety cells. ${ }^{14}$

If the reported plan type is 'DC' or 'both', then the survey asks for the balance accumulated in the plan. Missing data, although still a problem, is not as severe as for DB plans: for 71 percent of DC plans an account balance is reported. If the plan type is DC then further details on the type of plan are asked. Responses to, these detailed questions are used to categorize DC contributions as contributions to either ' $401(k)$ plans' or to 'traditional DC plans'. Our definition of '401(k) plans' broadly includes the HRS response categories '401(k)/403(b)/SRA', "thrift of saving plan," 'tax shelter',

\footnotetext{
${ }^{14} \mathrm{About} 9$ percent of the DB plans were also missing the expected age of retirement. We use the modal response of age 62 in these cases.
} 
'IRASEP', 'SEPP', or any response combination that includes these (i.e. some respondents indicate their plan was a combination of a $401(\mathrm{k})$ and a thrift plan). The category "traditional DC plans" covers the remaining types of DC plans, including ESOPs and money purchase plans. If a respondent indicated plan type 'both', then no detailed questions about plan type were asked. For these plans the entire balance is assumed to be in a "traditional DC plan," thus perhaps underestimating 401(k) balances. For plans known to be $\mathrm{DC}$, but for which the balance is unknown, the hotdeck imputation method is again used, based on plan number, plan type (traditional DC and 401(k)), and ten wage and salary income deciles.

Persons not currently employed are asked about their most recent job. As above, they can specify four pension types: DB, DC, both, and don't know (DK). However, each respondent could provide information on only one plan. In general, the follow-up questions parallel the questions asked for the current job discussed above. We will only note the differences here. First, persons covered by DB plans are asked about expected future benefits, benefits currently being received, and benefits already distributed as a lump-sum. We disregard all but the former because benefits currently received are picked up elsewhere in the survey (the income section, see below), and benefits already paid out will show up as IRA balances if rolled over (and do not represent pension wealth if not). If covered by a DC plan, the balance is only included if "left to accumulate" with the former employer. DC balances rolled-over into an IRA, converted to an annuity, or withdrawn are not included. Finally, if respondents who indicated coverage by 'both' plan types were asked "how much money was in your account when you left that employer?" The survey does not ask how much remains in the account as of the survey date. Based on the proportion of DC balances remaining with the employer to accumulate, we randomly include the balances of one-third of these respondents. Again, missing $D B$ benefits and DC data are imputed by the hotdeck method described above. Unfortunately, there is no way to distinguish between $401(\mathrm{k})$ balances and traditional DC plan balances acquired on prior jobs. Thus all DC balances are assumed to be from traditional DC plans. 
The final source of information on pension wealth is from income currently being received. We use income streams from pensions, annuities, and veterans benefits. There is no way to distinguish between DC and DB sources, so we report these data as a separate category (PV Benefits) in Tables 3 and 4.

\section{C.2. Constructing Pension Wealth}

For DC type pensions the reported balance is our measure of pension wealth. For persons expecting DB pension benefits and persons currently receiving pension income, we compute the present value of the benefit stream using the following assumptions: Mortality data are based on population averages by gender, age, and birth cohort provided by the Social Security Administration. See Mitchell, Olson, and Steinmeier (1996) for a discussion of these data. For discounting and earnings growth we use the "intermediate" interest rate assumptions used by the Social Security Administration. See Board of Trustees (1995). Public pensions are assumed to be fully indexed, again using the "intermediate" projections of the Social Security Administration. See Board of Trustees (1995). Private sector pension benefits are not indexed.

Respondents were asked to provide the expected pension benefit at their expected date of retirement. If benefits are not currently being received, they are assumed to commence at the expected age of retirement (the mean is 62). The average age of HRS respondents is 55 . Thus for the typical HRS respondent, retirement benefits do not begin for another seven years. We have assumed that their responses to the expected pension benefit question are denominated in future (date of retirement) dollars. Moreover, we have assumed that the benefit amount is a single survivor benefit. Accordingly, we use individual survival probabilities in the computation of the present value. If instead we assumed the responses represented joint survivor benefits, calculated pension wealth would be somewhat higher.

We further assume that when respondents report expected pension benefits they do not anticipate separating from their employer prior to retirement. This assumption allows us to calculate the present value of retirement wealth conditional on continued 
years of service until retirement. The component of this wealth "earned" as of the survey date is this present value multiplied by the ratio of years of service at the survey date to years of service at the expected date of retirement. This adjustment is necessary to make the present value of DB benefits comparable to the accumulated balance in a DC plan at the date of the survey. 


\section{REFERENCES}

Attanasio, Orazio, James Banks, Costas Meghir, and Guglielmo Weber. 1995. "Humps and Bumps in Lifetime Consumption." ERSC Working Paper No. W95/14.

Browning, Martin and Annamaria Lusardi. 1996. "Household Saving: Micro Theories and Macro Facts." Joumal of Economic Literature. Vol. 34. Pp. 1797-1855.

Davies, James B. 1982. "The Relative Impact of Inheritance and Other Factors on Economic Inequality." Quarterly Journal of Economics. Vol. 97. pp. 472-498.

Friedman, Milton. 1953. "Choice, Chance, and the Personal Distribution of Income." Joumal of Political Economy. Vol. 41. Pp. 277-290.

Hubbard, R. Glenn, Jonathan Skinner, and Stephen P. Zeldes. 1995. "Precautionary Saving and Social Insurance." Journal of Political Economy, vol. 103, no. 2., pp. 360-399.

Juster, F. Thomas and Richard Suzman. 1995. "An Overview of the Health and Retirement Study." Journal of Human Resources. Vol. 30. pp. s7-s56.

Juster, F. Thomas and James P. Smith. 1994. "Improving the Quality of Economic Data: Lessons from the HRS." July. Mimeograph.

Kessler, Denis and Andre Masson. 1988. Modelling the Accumulation and Distribution of Wealth. Oxford University Press.

Mitchell, Olivia, Jan Olson and Thomas Steinmeier. 1996. "Construction of the Earnings and Benefits File (EBF) for Use with the Health and Retirement Survey." NBER Working Paper No. 5707. August. 
Poterba, James M., Steven F. Venti, and David A. Wise. 1997. "Implications of Rising Personal Retirement Saving." Prepared for NBER Conference on the Economics of Aging, April.

Samwick, Andrew A. 1996. "Discount Rate Heterogeneity and Social Security Reform." Presented at 9th Annual Inter-American Seminar on Economics. Buenos Aires. November.

Shefrin, Hersh M., and Richard H. Thaler. 1988. "The Behavioral Life-Cycle Hypothesis." Economic Inquiry, vol. 26, pp. 609-643.

Shoven, John B. And David A. Wise. 1996. "The Taxation of Pensions: A Shelter Can Become a Trap." NBER Working Paper No. 5815. November.

1997. "Keeping Savers from Saving." In D. Wise (ed.), Facing the Aging Wave, Hoover Institution Press, forthcoming.

Smith, James D. 1980. Modeling the Distribution and Intergenerational Transmission of Wealth. University of Chicago Press.

Smith, James P. 1995. "Racial and Ethnic Differences in Wealth in the Health and Retirement Study." Journal of Human Resources. Vol. 30. pp. s158-s183.

Venti, Steven F. and David A. Wise. 1990. "Have IRAs Increased U.S. Saving?: Evidence from Consumer Expenditure Surveys." Quarterly Journal of Economics, August, pp. 661-698.

1997. "Lifetime Income, Saving Choices, and Wealth at Retirement."

Presented at the symposium to Honor F. Thomas Juster, December, 1996, revised. 
Wolff, Edward N. 1987. International Comparisons of the Distribution of Household Wealth. Oxford University Press. 


\begin{tabular}{|l|c|c|}
\hline \multicolumn{3}{|c|}{$\begin{array}{r}\text { Table 1. Comparison of HRS respondents for whom Social Security } \\
\text { data are and are not available. }\end{array}$} \\
\hline \multicolumn{1}{|c|}{ Characteristic } & $\begin{array}{c}\text { Persons without Social } \\
\text { Security records }\end{array}$ & $\begin{array}{c}\text { Persons with Social } \\
\text { Security records }\end{array}$ \\
\hline Mean household income & $\$ 54,252.64$ & $\$ 53,434.20$ \\
Percent female & $53.00 \%$ & $54.00 \%$ \\
Mean age & 55.57 & 55.40 \\
Percent non-white & $15.00 \%$ & $13.00 \%$ \\
Mean years of education & 12.37 & 12.40 \\
Percent married & $76.00 \%$ & $76.00 \%$ \\
Percent primary & $60.00 \%$ & $64.00 \%$ \\
respondent & & \\
\hline \multirow{2}{*}{ Weighted estimates from the HRS Wave I. } & \\
\hline
\end{tabular}




\begin{tabular}{|cc|}
\hline \multicolumn{2}{|c|}{ Table 2. Present value of SS earnings by lifetime income } \\
decile.
\end{tabular}




\begin{tabular}{|c|c|c|c|c|c|c|c|c|c|c|}
\hline \multirow{2}{*}{ Asset Category } & \multicolumn{10}{|c|}{ Income Decile } \\
\hline & $1^{8 t}$ & $2^{\text {nd }}$ & $3^{\text {rd }}$ & $4^{\text {th }}$ & $5^{\text {th }}$ & $6^{\text {th }}$ & $7^{\text {th }}$ & $8^{\text {th }}$ & $9^{\text {th }}$ & $10^{\text {th }}$ \\
\hline Financial Assets & 0 & 70 & 80 & 2000 & 3000 & 7000 & 9500 & 17000 & 25000 & 36500 \\
\hline $\begin{array}{l}\text { Pers. Retirement } \\
\text { Assets }\end{array}$ & 0 & 0 & 0 & 0 & 0 & 1500 & 5000 & 12000 & 25000 & 40000 \\
\hline IRA & 0 & 0 & 0 & 0 & 0 & 0 & 1700 & 5000 & 12000 & 21000 \\
\hline $401(k)$ & 0 & 0 & 0 & 0 & 0 & 0 & 0 & 0 & 0 & 0 \\
\hline Traditional Pension & 0 & 0 & 0 & 0 & 4000 & 14035 & 33793 & 40808 & 58000 & 83259 \\
\hline Defined Contribution & 0 & 0 & 0 & 0 & 0 & 0 & 0 & 0 & 0 & 0 \\
\hline Defined Benefit & 0 & 0 & 0 & 0 & 0 & 0 & 0 & 1497 & 3083 & 22690 \\
\hline Pv Pension Income & 0 & 0 & 0 & 0 & 0 & 0 & 0 & 0 & 0 & 0 \\
\hline Vehicles & 300 & 1700 & 3000 & 5000 & 6000 & 8000 & 10000 & 10000 & 12000 & 15000 \\
\hline Business Equity & 0 & 0 & 0 & 0 & 0 & 0 & 0 & 0 & 0 & 0 \\
\hline Other Real Estate & 0 & 0 & 0 & 0 & 0 & 0 & 0 & 0 & 0 & 3000 \\
\hline Home Equity & 0 & 8000 & 19000 & 23000 & 29000 & 39000 & 50000 & 60000 & 70000 & 77000 \\
\hline Home Value & 0 & 17000 & 35000 & 35000 & 45000 & 67000 & 75000 & 85000 & 100000 & 120000 \\
\hline Mortgage Debt & 0 & 0 & 0 & 0 & 0 & 9000 & 5600 & 11000 & 15000 & 20000 \\
\hline Ss Wealth & 0 & 54754 & 75335 & 88692 & 101234 & 108619 & 117764 & 119950 & 137673 & 175542 \\
\hline Total Wealth Excl. SS & 5000 & 34429 & 52803 & 82620 & 105166 & 144188 & 189832 & 221692 & 305536 & 387609 \\
\hline Total Wealth Incl. SS & 33006 & 85448 & 125759 & 168878 & 203084 & 261072 & 312037 & 349549 & 453265 & $57 ? 107$ \\
\hline
\end{tabular}




\begin{tabular}{|c|c|c|c|c|c|c|c|c|c|c|}
\hline \multirow{2}{*}{ Asset Category } & \multicolumn{10}{|c|}{ Income Decile } \\
\hline & $1^{\text {st }}$ & $2^{\text {nd }}$ & $3^{\text {rd }}$ & $4^{\text {th }}$ & $5^{\text {th }}$ & $6^{\text {th }}$ & $7^{\text {th }}$ & $8^{\text {th }}$ & $9^{\text {th }}$ & $10^{\text {th }}$ \\
\hline Financial Assets & 20566 & 16369 & 18635 & 31871 & 34245 & 36988 & 50339 & 56837 & 112356 & 88420 \\
\hline $\begin{array}{l}\text { Pers. Retirement } \\
\text { Assets }\end{array}$ & 5628 & 4337 & 6266 & 10185 & 10340 & 16000 & 28291 & 40531 & 65461 & 76454 \\
\hline IRA & 3730 & 3683 & 4325 & 6843 & 8035 & 11219 & 18904 & 24528 & 39391 & 52706 \\
\hline $401(k)$ & 1898 & 654 & 1941 & 3341 & 2305 & 4781 & 9386 & ; 16003 & 26070 & 23748 \\
\hline Traditional Pension & 12382 & 19285 & 22301 & 32603 & 38107 & 55383 & 79646 & 91843 & 132369 & 145626 \\
\hline Defined Contribution & 20 & 2008 & 2498 & 4431 & 3461 & 5137 & 8886 & 14193 & 22498 & 18185 \\
\hline Defined Benefit & 8224 & 8563 & 11436 & 17089 & 18821 & 28614 & 37574 & 50684 & 73454 & $9: 074$ \\
\hline Pv Pension Income & 4138 & 8713 & 8 & 11083 & 15825 & 21633 & 33206 & 26966 & 36416 & $3<367$ \\
\hline Vehicles & 3353 & 4291 & 7022 & 8519 & 11155 & 12691 & 18694 & 15700 & 16142 & 19698 \\
\hline Business Equity & 85 & 2884 & 5107 & 23140 & 42628 & 28716 & 45793 & 27982 & 78164 & 55817 \\
\hline Other Real Estate & 19213 & 12884 & 20548 & 39257 & 38350 & 54481 & 45940 & 55894 & 57611 & 80771 \\
\hline Home Equity & 17842 & 32488 & 33129 & 38941 & 44342 & 53143 & 65596 & 73628 & 91297 & 98326 \\
\hline Home Value & 23997 & 43997 & 46674 & 57834 & 62417 & 76721 & 96452 & 104887 & 126176 & 139148 \\
\hline Mortgage Debt & 6155 & 11508 & 13544 & 18893 & 18076 & 23578 & 30857 & 31259 & 34879 & $4 C 821$ \\
\hline Ss Wealth & 16494 & 49665 & 67962 & 82951 & 95980 & 108749 & 116674 & 119172 & 135626 & 172476 \\
\hline Total Wealth Excl. SS & 79069 & 92538 & 113009 & 184515 & 219166 & 257402 & 334298 & 362413 & 553400 & 565112 \\
\hline Total Wealth Incl. SS & 95563 & 142203 & 180971 & 267466 & 315146 & 366151 & 450972 & 481586 & 689026 & 737588 \\
\hline
\end{tabular}


Table 5. Percent reduction in residual variance of total wealth, by control variables.

\section{Total Sample}

Control Variables

Percent Reduction versus

Unconditional Standard

Deviation
A. Lifetime Income Decile
5.05
B. A plus Chance Variables
9.08
C. A plus Investment Choice Variables
12.98
D. A plus $B$ plus $C$
15.32
E. D plus "Taste Variables" (Education and Race)
16.00

\begin{tabular}{|c|c|c|c|c|}
\hline \multicolumn{5}{|c|}{ By Lifetime Income Decile } \\
\hline \multirow[b]{2}{*}{ Decile } & \multicolumn{4}{|c|}{ Control Variables } \\
\hline & $\begin{array}{l}\text { B. Chance } \\
\text { Variables }\end{array}$ & $\begin{array}{l}\text { C. Investment } \\
\text { Choice } \\
\text { Variables }\end{array}$ & D. B plus $C$ & $\begin{array}{c}\text { E. D plus } \\
\text { "Taste } \\
\text { Variables" } \\
\text { (Education and } \\
\text { Race) }\end{array}$ \\
\hline $1^{\text {stst }}$ & 6.84 & 7.18 & 10.29 & 10.12 \\
\hline $2 n d$ & 23.15 & 8.29 & 26.41 & 27.90 \\
\hline 3rd & 1.47 & 9.39 & 10.33 & 10.54 \\
\hline 4th & 26.55 & 15.01 & 32.67 & 32.83 \\
\hline 5 th & 3.35 & 16.30 & 16.91 & 17.82 \\
\hline 6th & 5.22 & 12.17 & 14.29 & 25.58 \\
\hline 7th & 9.88 & 13.78 & 19.52 & 20.70 \\
\hline 8th & 2.32 & 13.53 & 13.67 & 15.45 \\
\hline 9th & 1.88 & 19.67 & 19.76 & 19.98 \\
\hline 10th & 4.00 & 17.52 & 19.49 & 21.02 \\
\hline \multicolumn{5}{|c|}{$\begin{array}{l}\text { Notes. } \\
\text { 1. Because shares could not be computed if total wealth is less than or equal to zero, only } \\
\text { families with positive levels of total wealth are used. } \\
\text { 2. The following investment shares were used: financial assets, personal retirement saving, } \\
\text { traditionai pension assecs, Dusiness equicy, verivies, irome equily, and other real cstate. }\end{array}$} \\
\hline
\end{tabular}




\begin{tabular}{|c|c|c|c|c|c|c|c|c|c|c|c|c|}
\hline \multirow{3}{*}{$\begin{array}{l}\text { Income } \\
\text { Decile }\end{array}$} & \multicolumn{12}{|c|}{ Saving rate $s$ and rate of return $r$} \\
\hline & \multicolumn{2}{|c|}{$s=.05, r=6 \%$} & \multicolumn{2}{|c|}{$s=.05, r=12.5 \%$} & \multicolumn{2}{|c|}{$s=.10, r=6 \%$} & \multicolumn{2}{|c|}{$s=.10, r=12.5 \%$} & \multicolumn{2}{|c|}{$s=.15, r=6 \%$} & \multicolumn{2}{|c|}{$s=15, r=12.5 \%$} \\
\hline & SS & CPS & SS & CPS & SS & CPS & SS & CPS & SS & CPS & SS & CPS \\
\hline $1^{\text {st }}$ & 1,608 & 34 & 4,329 & 137 & 3,216 & 69 & 8,658 & 275 & 4,824 & 103 & 12.987 & 412 \\
\hline $2^{\text {nd }}$ & 9,178 & 11,402 & 24,887 & 38,066 & 18,356 & 22,804 & 49,773 & 76,133 & 27,534 & 34,207 & 74.560 & 144,199 \\
\hline $3^{\text {rd }}$ & 18,321 & 23,738 & 50,004 & 73,290 & 36,642 & 47,475 & 100,008 & 146,580 & 54,962 & 71,213 & 150.012 & 219,870 \\
\hline $4^{\text {th }}$ & 28,236 & 33,627 & 78,897 & 100,608 & 56,472 & 67,253 & 157,794 & 201,216 & 84,708 & 100,880 & 236690 & 301,825 \\
\hline $5^{\text {th }}$ & 37,083 & 42,606 & 105,962 & 124,198 & 74,166 & 85,212 & 211,925 & 248,395 & 111,249 & 127,819 & 317887 & 372,593 \\
\hline $6^{\text {th }}$ & 45,490 & 51,079 & 125,965 & 144,557 & 90,981 & 102,158 & 251,930 & 289,113 & 136,471 & 153,237 & 377.896 & 433,670 \\
\hline $7^{\text {th }}$ & 53,617 & 61,056 & 150,462 & 173,856 & 107,234 & 122,112 & 300,923 & 347,712 & 160,851 & 183,168 & 451.385 & 521,567 \\
\hline $8^{\text {th }}$ & 60,073 & 71,689 & 163,745 & 199,094 & 120,147 & 143,378 & 327,490 & 398,189 & 180,220 & 215,068 & 491.236 & 597,283 \\
\hline $9^{\text {th }}$ & 67,457 & 88,701 & 183,935 & 251,229 & 134,914 & 177,401 & 367,869 & 502,459 & 202,370 & 266,102 & 551804 & 753,688 \\
\hline $10^{\text {th }}$ & 83,810 & 125,418 & 226,230 & 354,536 & 167,620 & 250,835 & 452,460 & 709,072 & 251,430 & 376,153 & 678.690 & $1.063,609$ \\
\hline All & 40,487 & 50,935 & 111,442 & 145,957 & 80,975 & 101,870 & 222,883 & 291,914 & 121,462 & 152,805 & 334.325 & 437,872 \\
\hline
\end{tabular}




\begin{tabular}{|c|c|c|}
\hline \multicolumn{3}{|c|}{$\begin{array}{c}\text { Table 7. Actual median total financial assets (personal } \\
\text { retirement, firm pension, and other financial) and total } \\
\text { wealth, by lifetime income decile. }\end{array}$} \\
\hline $\begin{array}{c}\text { Lifetime Income } \\
\text { Decile }\end{array}$ & $\begin{array}{c}\text { Total Financial } \\
\text { Assets }\end{array}$ & Total Wealth \\
\hline 1st & 0 & 3000 \\
2nd & 431 & 28800 \\
3rd & 6770 & 47025 \\
4th & 22000 & 72504 \\
5th & 35668 & 105166 \\
6th & 46882 & 126082 \\
7th & 86000 & 195000 \\
8th & 111465 & 224000 \\
9th & 162825 & 305536 \\
10th & 213855 & 380115 \\
\hline
\end{tabular}




\begin{tabular}{|c|c|c|c|c|}
\hline Question & Response & $\begin{array}{c}\text { Perce } \\
\text { nt }\end{array}$ & \begin{tabular}{|c|} 
Total \\
Wealt \\
$\mathrm{h}$ \\
$\mathrm{Q}$
\end{tabular} & $\begin{array}{l}\text { Total } \\
\text { Fin } \\
\text { Asset } \\
\text { Q }\end{array}$ \\
\hline $\begin{array}{l}\text { Over the past } 20 \text { or } 30 \\
\text { years do you think now } \\
\text { what you saved was (M9- } \\
\text { 4): }\end{array}$ & $\begin{array}{l}\text { About right } \\
\text { Too little } \\
\text { Too much* }\end{array}$ & $\begin{array}{l}24 \% \\
76 \%\end{array}$ & $\begin{array}{l}61 \\
46\end{array}$ & $\begin{array}{l}64 \\
43\end{array}$ \\
\hline $\begin{array}{l}\text { If you could do it again do } \\
\text { you think you would save } \\
\text { (M9-4c): }\end{array}$ & $\begin{array}{l}\text { About the } \\
\text { same } \\
\text { More } \\
\text { Less\# }\end{array}$ & $\begin{array}{l}31 \% \\
69 \%\end{array}$ & $\begin{array}{l}57 \\
45\end{array}$ & $\begin{array}{l}55 \\
44\end{array}$ \\
\hline $\begin{array}{l}\text { Including Social Security } \\
\text { and pensions will you have } \\
\text { enough saving to maintain } \\
\text { your living standard after } \\
\text { retirement (M10-10): }\end{array}$ & $\begin{array}{l}\text { Yes } \\
\text { No }\end{array}$ & $\begin{array}{l}67 \% \\
33 \%\end{array}$ & $\begin{array}{l}58 \\
46\end{array}$ & $\begin{array}{l}57 \\
46\end{array}$ \\
\hline $\begin{array}{l}\text { If yes: How do you } \\
\text { expect your standard } \\
\text { of living in retirement } \\
\text { to compare to your } \\
\text { present standard of } \\
\text { living (M10-11f): }\end{array}$ & $\begin{array}{l}\text { Higher } \\
\text { Same } \\
\text { Lower }\end{array}$ & $\begin{array}{l}8 \% \\
75 \% \\
17 \%\end{array}$ & $\begin{array}{l}44 \\
60 \\
60\end{array}$ & $\begin{array}{l}50 \\
58 \\
54\end{array}$ \\
\hline
\end{tabular}




\begin{tabular}{|c|c|c|c|c|}
\hline Question & Response & $\begin{array}{c}\text { Percen } \\
t\end{array}$ & $\begin{array}{c}\text { Total } \\
\text { Wealth } \\
\mathbf{Q}\end{array}$ & $\begin{array}{l}\text { Total } \\
\text { Fin } \\
\text { Asset } \\
Q\end{array}$ \\
\hline $\begin{array}{l}\text { At what age did you start } \\
\text { saving for retirement (M9-3): }\end{array}$ & \begin{tabular}{|l}
$\leq 25$ \\
$26-35$ \\
$36-45$ \\
$46-55$ \\
$\geq 56$ \\
Never
\end{tabular} & $\begin{array}{c}13 \% \\
17 \% \\
21 \% \\
20 \% \\
3 \% \\
26 \%\end{array}$ & $\begin{array}{l}63 \\
57 \\
54 \\
48 \\
47 \\
37\end{array}$ & $\begin{array}{l}58 \\
56 \\
53 \\
49 \\
45 \\
34\end{array}$ \\
\hline $\begin{array}{l}\text { Thinking over the past } 20 \text { or } 30 \\
\text { years did you have some target } \\
\text { or planned level of saving (M9- } \\
5 \text { ) }\end{array}$ & $\begin{array}{l}\text { Yes } \\
\text { No }\end{array}$ & $\begin{array}{l}23 \% \\
77 \%\end{array}$ & $\begin{array}{l}56 \\
48\end{array}$ & $\begin{array}{l}54 \\
46\end{array}$ \\
\hline $\begin{array}{l}\text { If yes: Did you have a plan } \\
\text { for achieving that goal } \\
\text { (M9-5a): }\end{array}$ & $\begin{array}{l}\text { Yes } \\
\text { No }\end{array}$ & $\begin{array}{l}81 \% \\
19 \%\end{array}$ & $\begin{array}{l}59 \\
55\end{array}$ & $\begin{array}{l}56 \\
47\end{array}$ \\
\hline $\begin{array}{l}\text { If yes: Did the plan include } \\
\text { trying to save something } \\
\text { out of each paycheck (M9- } \\
\text { 5b) }\end{array}$ & $\begin{array}{l}\text { Yes } \\
\text { No }\end{array}$ & $\begin{array}{c}92 \% \\
8 \%\end{array}$ & $\begin{array}{l}59 \\
36\end{array}$ & $\begin{array}{l}56 \\
41\end{array}$ \\
\hline $\begin{array}{l}\text { Over the past years did you } \\
\text { have a plan for retirement } \\
\text { saving (M10-4): }\end{array}$ & $\begin{array}{l}\text { Yes } \\
\text { No }\end{array}$ & $\begin{array}{l}47 \% \\
53 \%\end{array}$ & $\begin{array}{l}60 \\
48\end{array}$ & $\begin{array}{l}63 \\
44\end{array}$ \\
\hline $\begin{array}{l}\text { How well do these statements } \\
\text { describe you -- } 0 \text { means } \\
\text { doesn't, } 10 \text { means closely } \\
\text { (M10-20): }\end{array}$ & & & & \\
\hline $\begin{array}{l}\text { I never seemed to get } \\
\text { caught up on my bills so I } \\
\text { could save for the future: }\end{array}$ & $\begin{array}{l}0 \text { to } 3 \\
4 \text { to } 6 \\
7 \text { to } 10 \\
\end{array}$ & $\begin{array}{l}43 \% \\
28 \% \\
28 \% \\
\end{array}$ & $\begin{array}{l}53 \\
57 \\
51\end{array}$ & $\begin{array}{l}54 \\
58 \\
47 \\
\end{array}$ \\
\hline $\begin{array}{l}\text { I could never stick to a } \\
\text { saving plan: }\end{array}$ & $\begin{array}{l}0 \text { to } 3 \\
4 \text { to } 6 \\
7 \text { to } 10\end{array}$ & $\begin{array}{l}44 \% \\
26 \% \\
30 \% \\
\end{array}$ & $\begin{array}{l}57 \\
50 \\
53 \\
\end{array}$ & $\begin{array}{l}61 \\
45 \\
51\end{array}$ \\
\hline
\end{tabular}




\begin{tabular}{|c|c|c|c|c|}
\hline Question & Response & $\begin{array}{c}\text { Percen } \\
t\end{array}$ & $\begin{array}{c}\text { Total } \\
\text { Wealth } \\
\mathbf{Q}\end{array}$ & $\begin{array}{l}\text { Total } \\
\text { Fin } \\
\text { Asset } \\
\mathbf{Q}\end{array}$ \\
\hline $\begin{array}{l}\text { I thought Social Security } \\
\text { or employer pensions } \\
\text { would take care of my } \\
\text { retirement income: }\end{array}$ & $\begin{array}{l}0 \text { to } 3 \\
4 \text { to } 6 \\
7 \text { to } 10\end{array}$ & $\begin{array}{l}44 \% \\
28 \% \\
28 \%\end{array}$ & $\begin{array}{l}58 \\
52 \\
50\end{array}$ & $\begin{array}{l}59 \\
52 \\
46\end{array}$ \\
\hline $\begin{array}{l}\text { If you put } \$ 10,000 \text { in a saving } \\
\text { account when age } 25, \text { how } \\
\text { much would you have now, at a } \\
5 \% \text { interest rate: }\end{array}$ & \begin{tabular}{|l|}
$<\$ 35,000$ \\
$\$ 35,000-$ \\
75,000 \\
$\$ 75,000-$ \\
$\$ 105,000$ \\
$>\$ 105,000$
\end{tabular} & $\begin{array}{l}16 \% \\
33 \% \\
29 \% \\
22 \%\end{array}$ & $\begin{array}{l}54 \\
46 \\
48 \\
58\end{array}$ & $\begin{array}{l}52 \\
45 \\
46 \\
58\end{array}$ \\
\hline $\begin{array}{l}\text { Thinking of your planning for } \\
\text { retirement over the past } 20 \text { or } \\
30 \text { years how important did you } \\
\text { think the following sources } \\
\text { would be in providing your } \\
\text { retirement income -- } 0 \text { means } \\
\text { unimportant, } 10 \text { means very } \\
\text { important (M9-2): }\end{array}$ & & & & \\
\hline Social Security: & $\begin{array}{l}0 \text { to } 3 \\
4 \text { to } 6 \\
7 \text { to } 10\end{array}$ & $\begin{array}{c}8 \% \\
24 \% \\
68 \%\end{array}$ & $\begin{array}{l}68 \\
54 \\
47\end{array}$ & $\begin{array}{l}55 \\
49 \\
48\end{array}$ \\
\hline $\begin{array}{l}\text { Employer-provided } \\
\text { pension: }\end{array}$ & $\begin{array}{l}0 \text { to } 3 \\
4 \text { to } 6 \\
7 \text { to } 10 \\
\end{array}$ & $\begin{array}{l}23 \% \\
16 \% \\
62 \% \\
\end{array}$ & $\begin{array}{l}44 \\
41 \\
55\end{array}$ & $\begin{array}{l}41 \\
39 \\
54\end{array}$ \\
\hline IRAs, 401(k), or KEOGH: & $\begin{array}{l}0 \text { to } 3 \\
4 \text { to } 6 \\
7 \text { to } 10\end{array}$ & $\begin{array}{l}36 \% \\
22 \% \\
41 \% \\
\end{array}$ & $\begin{array}{l}45 \\
49 \\
54 \\
\end{array}$ & $\begin{array}{l}39 \\
47 \\
56\end{array}$ \\
\hline $\begin{array}{l}\text { Other personal saving or } \\
\text { investment: }\end{array}$ & $\begin{array}{l}0 \text { to } 3 \\
4 \text { to } 6 \\
7 \text { to } 10\end{array}$ & $\begin{array}{l}21 \% \\
27 \% \\
52 \% \\
\end{array}$ & $\begin{array}{l}36 \\
45 \\
58\end{array}$ & $\begin{array}{l}33 \\
42 \\
57\end{array}$ \\
\hline Other sources: & $\begin{array}{l}0 \text { to } 3 \\
4 \text { to } 6 \\
7 \text { to } 10\end{array}$ & $\begin{array}{l}47 \% \\
31 \% \\
23 \%\end{array}$ & $\begin{array}{l}44 \\
51 \\
61\end{array}$ & $\begin{array}{l}44 \\
50 \\
54\end{array}$ \\
\hline
\end{tabular}




\begin{tabular}{|c|l|c|c|c|}
\hline \multicolumn{4}{|c|}{ Table 10. Financial concerns versus Q. } \\
\hline Question & Response & $\begin{array}{c}\text { Percen } \\
t\end{array}$ & $\begin{array}{c}\text { Total } \\
\text { Wealth } \\
\text { Q }\end{array}$ & $\begin{array}{c}\text { Total } \\
\text { Fin } \\
\text { Asset } \\
\mathbf{Q}\end{array}$ \\
\hline $\begin{array}{l}\text { In thinking about your financial } \\
\text { future how concerned are you } \\
\text { with (M9-7): }\end{array}$ & & & & \\
\hline Health care costs: & Hardly & $19 \%$ & 54 & 50 \\
& Some & $29 \%$ & 52 & 53 \\
& A lot & $52 \%$ & 47 & 44 \\
\hline Job loss: & Hardly & $67 \%$ & 55 & 52 \\
& Some & $15 \%$ & 44 & 50 \\
\hline Ainancial market collapse: & Hardly & $18 \%$ & 39 & 36 \\
\hline & Some & $31 \%$ & 45 & 43 \\
& A lot & $26 \%$ & 53 & 55 \\
\hline Costs of supporting & Hardly & & & \\
parents: & Some & & & \\
\hline Costs of supporting & A lot & & & \\
\hline children: & Hardly & & & \\
& Some & & & \\
\hline
\end{tabular}




\section{Figure 1a. Wealth Quantiles}

1200000

1000000

Total Wealth

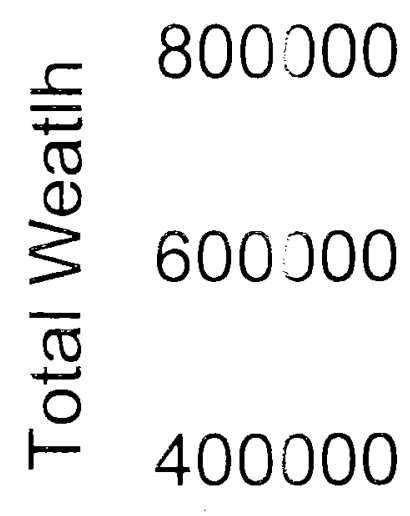

200000

0

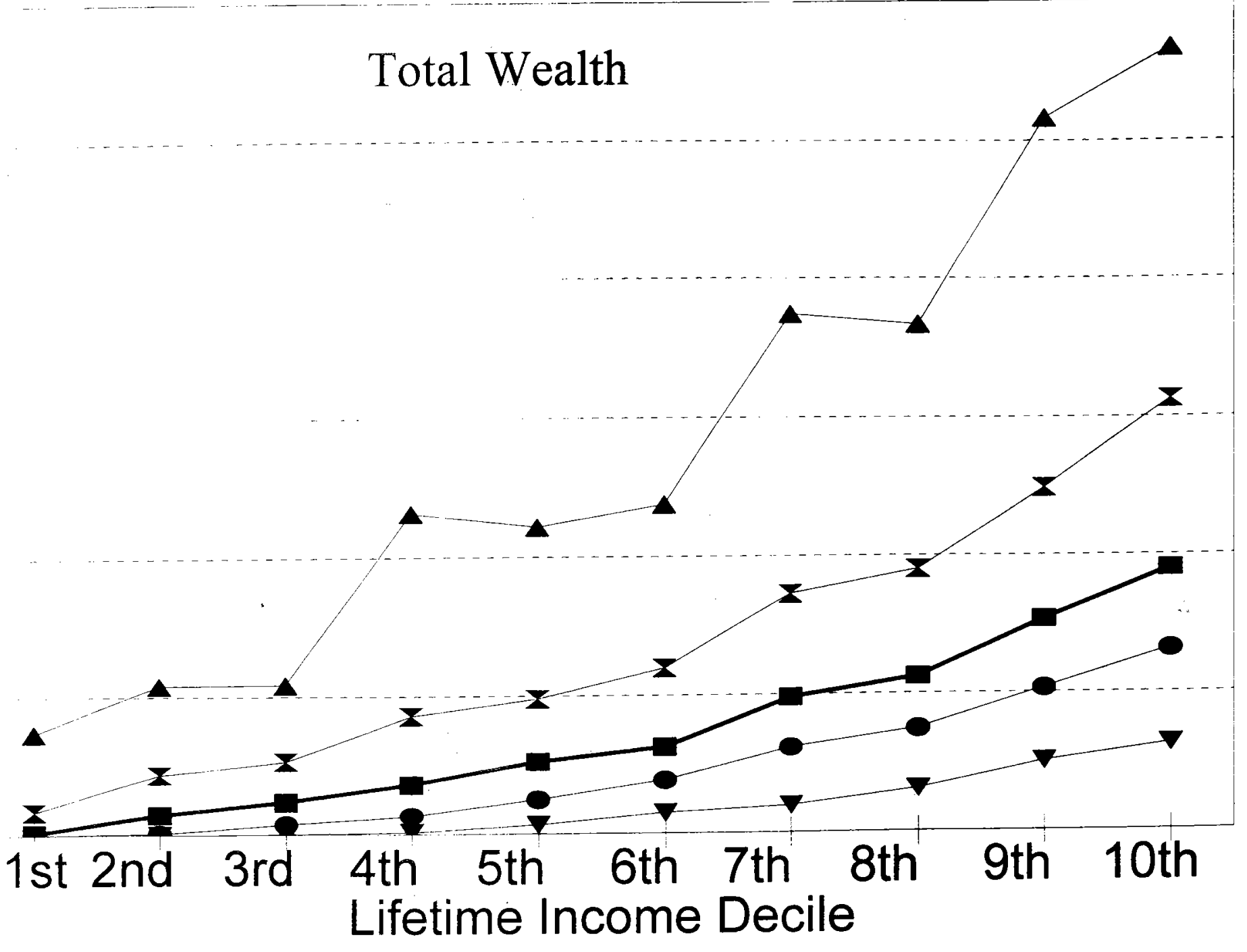

$\checkmark$ 10th $\bullet$ 30th $\rightarrow-50$ th $\simeq$ 70th $\triangle$ 90th 


\section{Figure 1b. Top Wealth Quantiles}

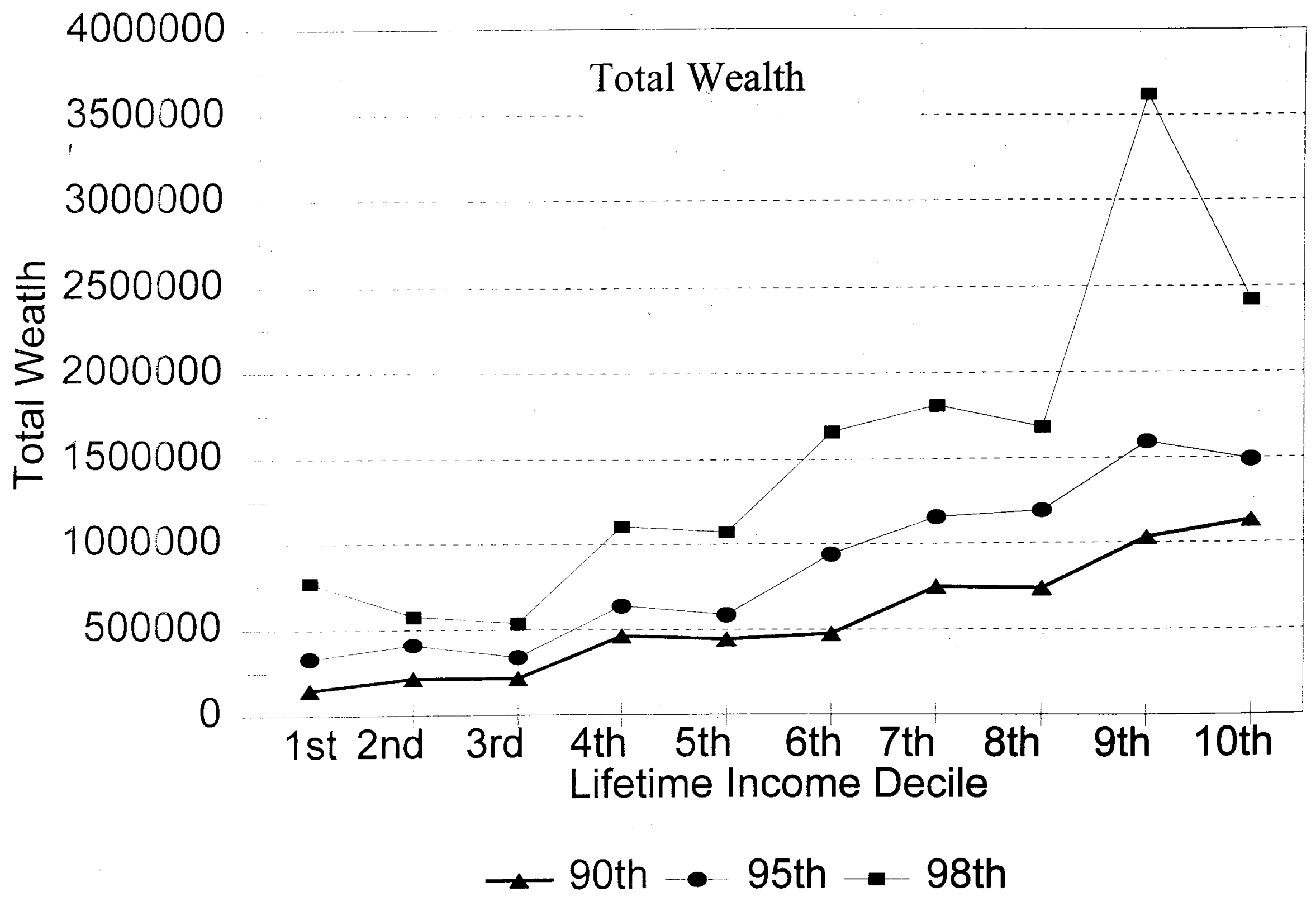




\section{Figure 2a. Wealth Quantiles}

250000

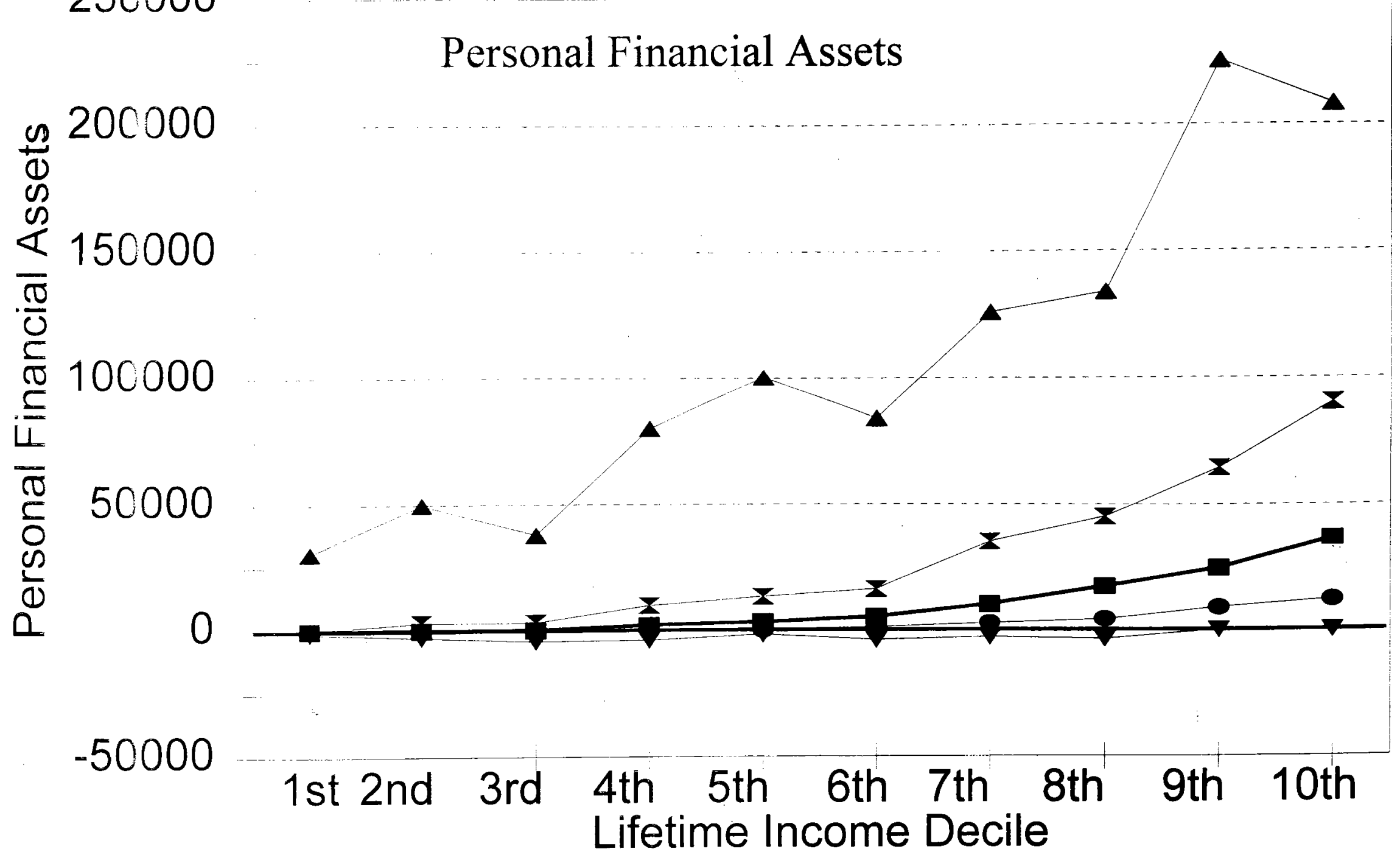

$\checkmark$ 10th - 30th $\rightarrow$ 50th -70 th $\leftarrow$ 90th 


\section{Figure 2b. Top Wealth Quantiles}

800000
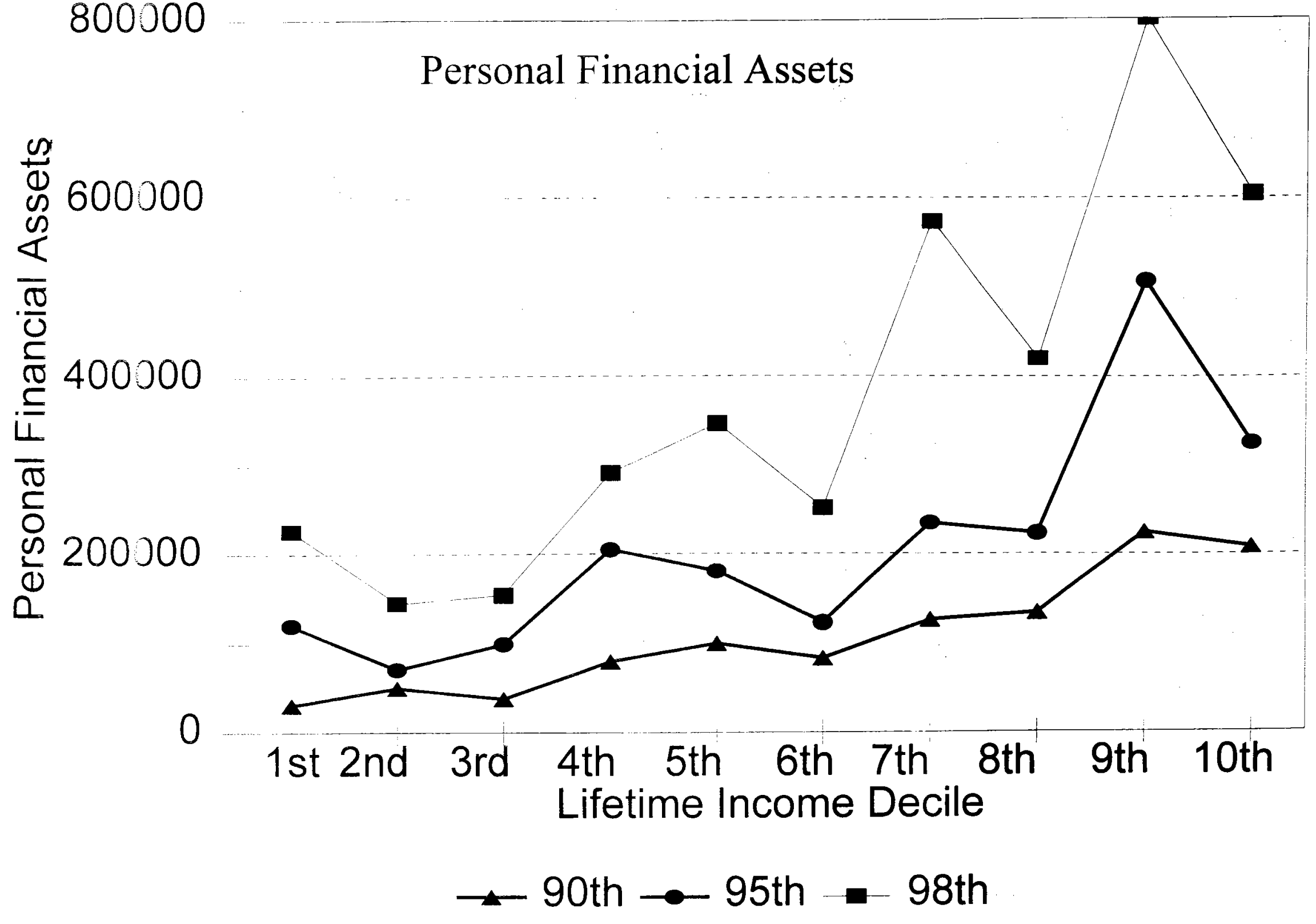

0 


\section{Figure 3a. Wealth Quantiles}

200000

Personal Retirement Assets

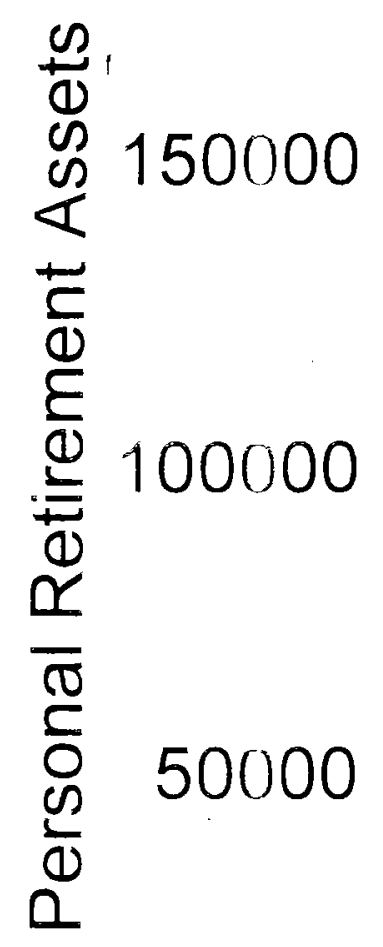

0

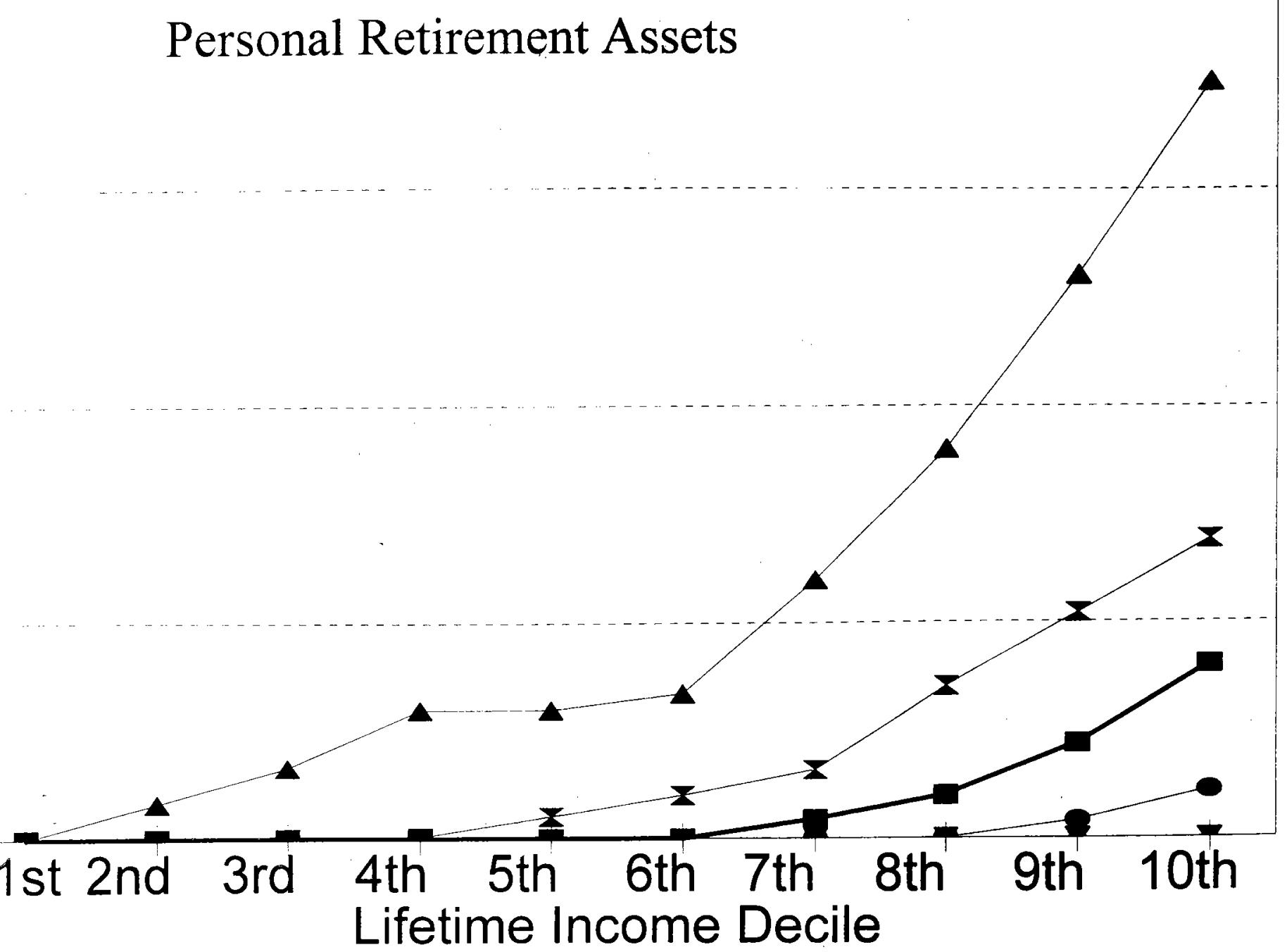

$\checkmark$ 10th $\bullet$ 30th $\rightarrow$ 50th $\leq$ 70th $\triangle$ 90th 


\section{Figure 3b. Top Wealth Quantiles}

600000

\section{Personal Retirement Assets}

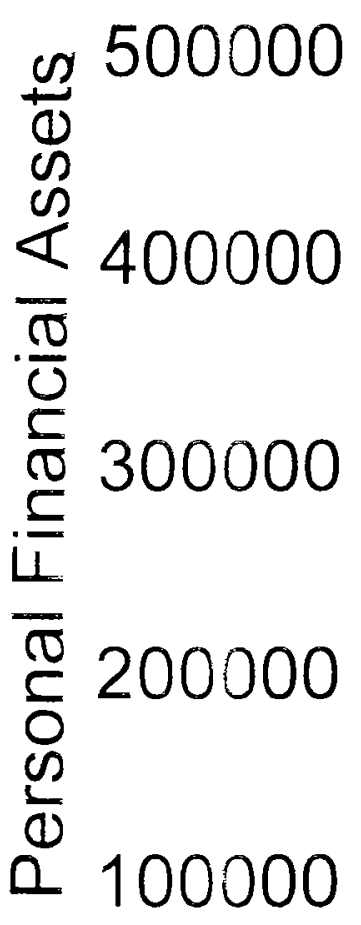

0

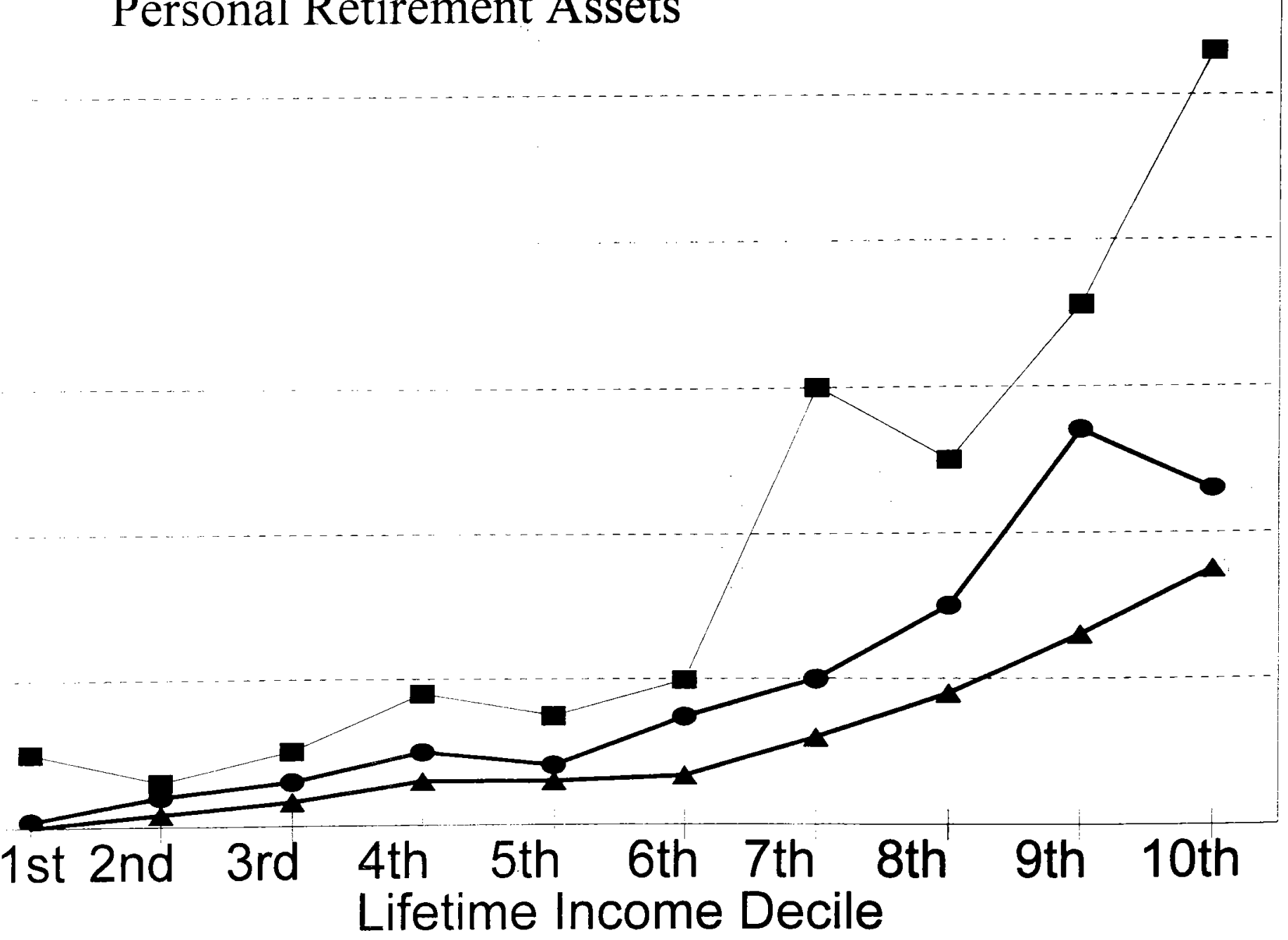

$\leftarrow$ 90th $\bullet-95$ th -98 th 
Fig 4. 1st Income Decile Adjusted v Unadjusted Wealth Quantiles
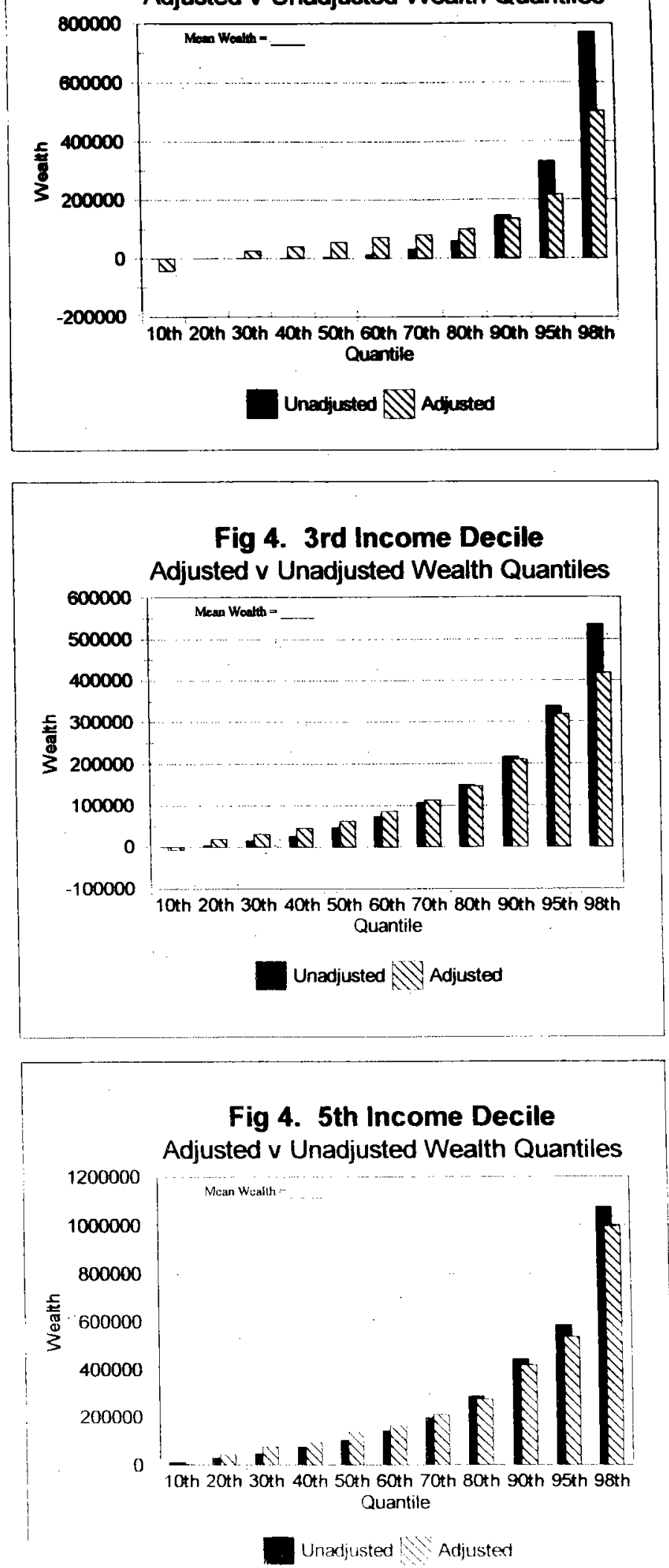

Fig 4. 2nd Income Decile Adjusted v Unadjusted Wealth Quantiles
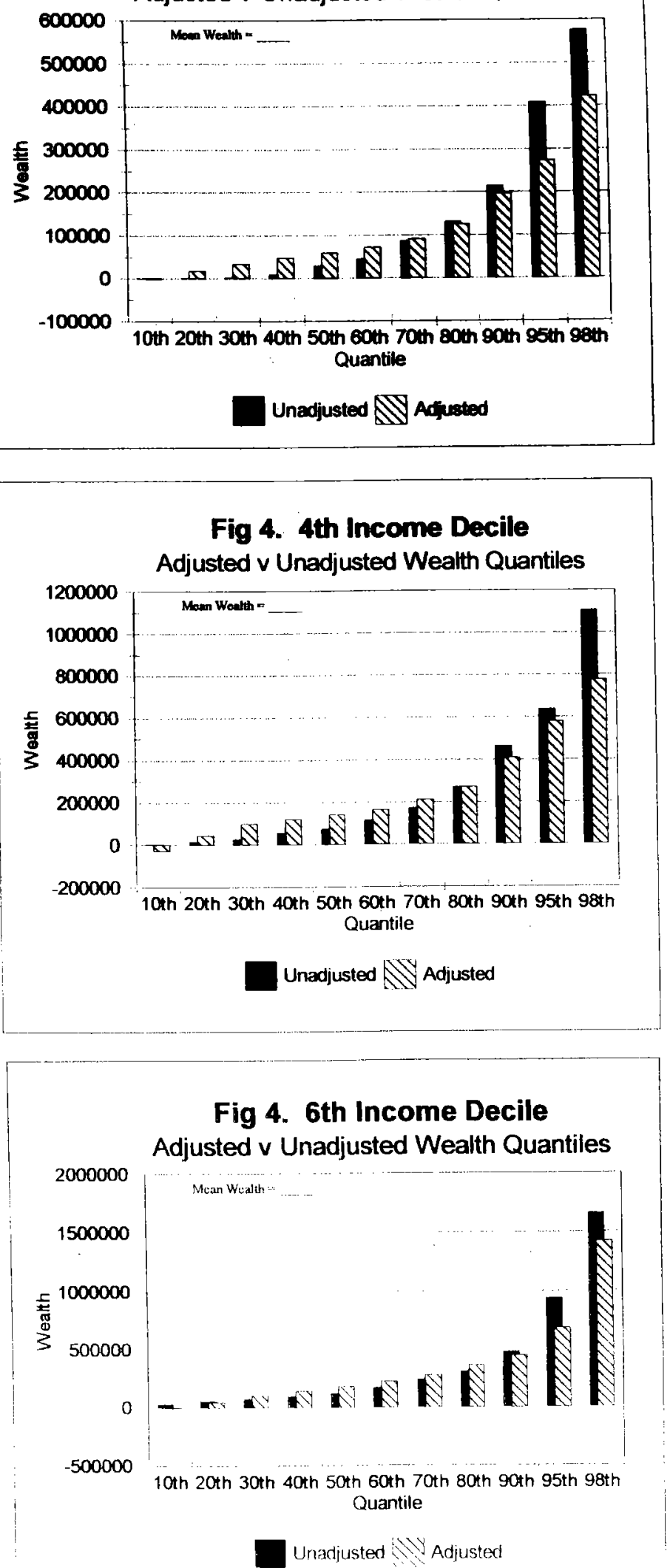
Fig 4. 1st Income Decile Adjusted v Unadjusted Wealth Quantiles

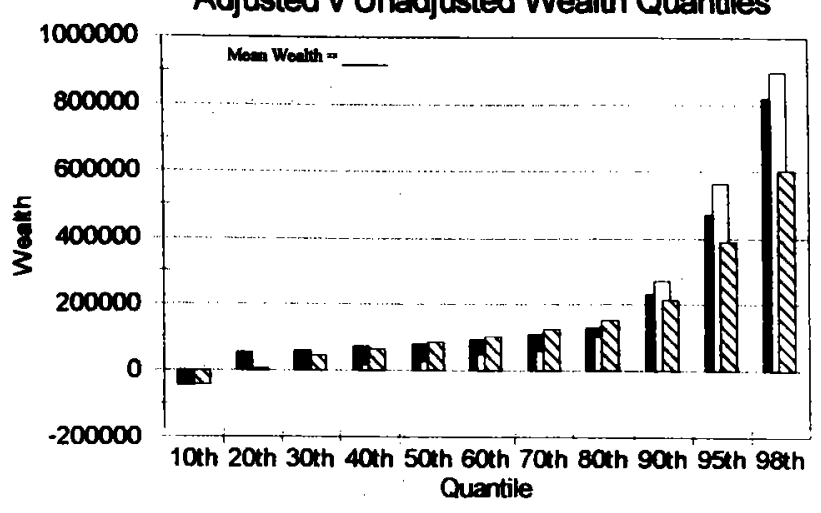

Imvestment Adjust $\square$ Unadjusted Chance Var Adjust
Fig 4. 2nd Income Decile

Adjusted v Unadjusted Wealth Quantiles

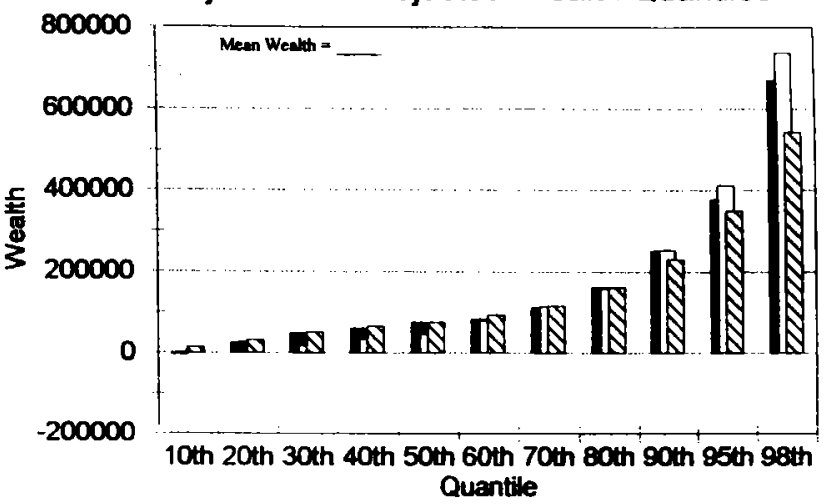

Investment Adjust $\square$ Unadjusted
Fig 4. 3rd Income Decile Adjusted v Unadjusted Wealth Quantiles

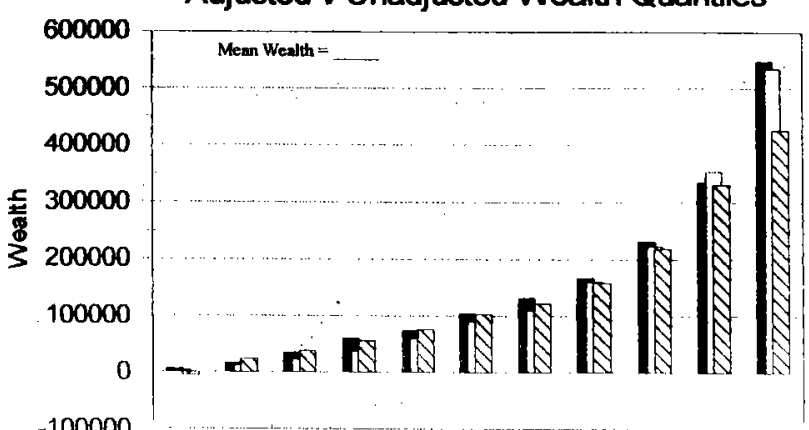

10th 20th 30th 40th 50th 60th 70th 80th 90th 95th 98th Quantile

Investment Adjust | Unadjusted AJ Chance Var Adjust
Fig 4. 4th Income Decile -Adjusted v Unadjusted Wealth Quantiles

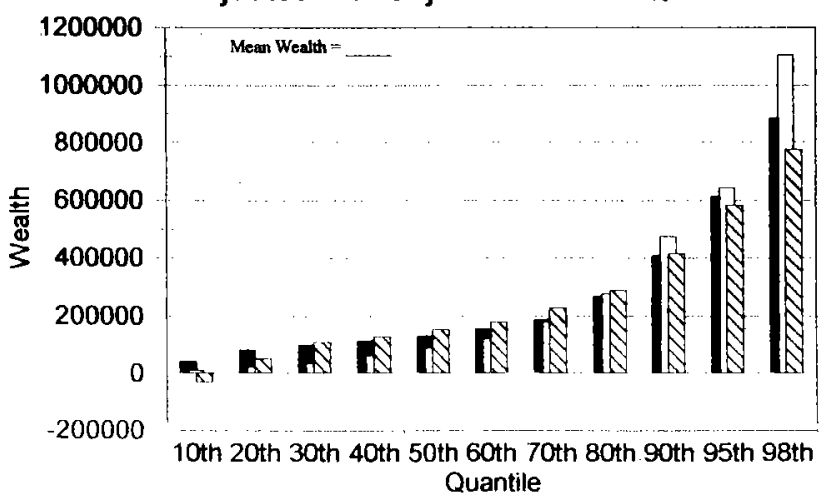

Investment Adjust | | Unadjusted AV Chance Var Adjust

Fig 4. 6th Income Decile Adjusted $v$ Unadjusted Wealth Quantiles

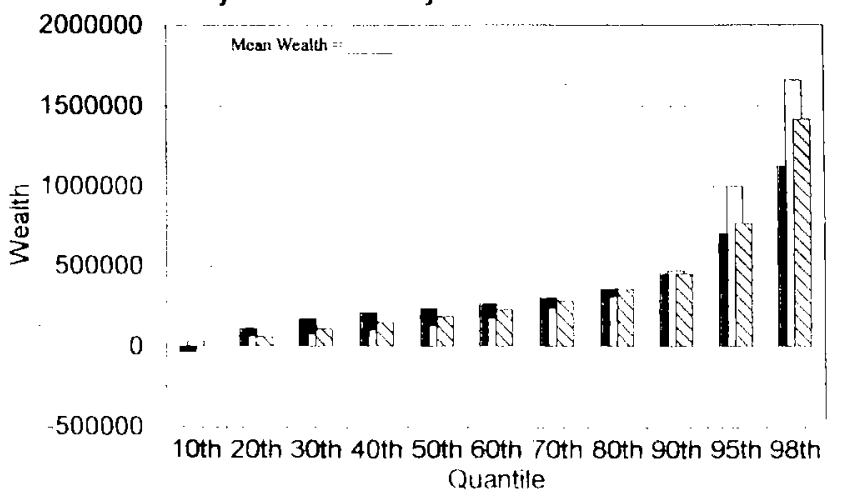

Investment Adjust Unadjusted Chance Val Adjust 
Fig 4. 7th Income Decile Adjusted v Unadjusted Wealth Quantiles

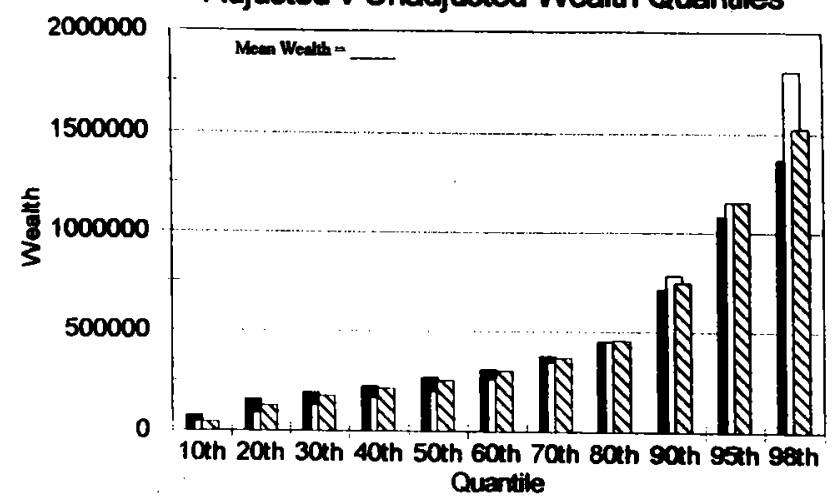

Investment Adjust $\square$ Unadjusted

N Chance Var Adjust

Fig 4. 9th Income Decile Adjusted v Unadjusted Wealth Quantiles

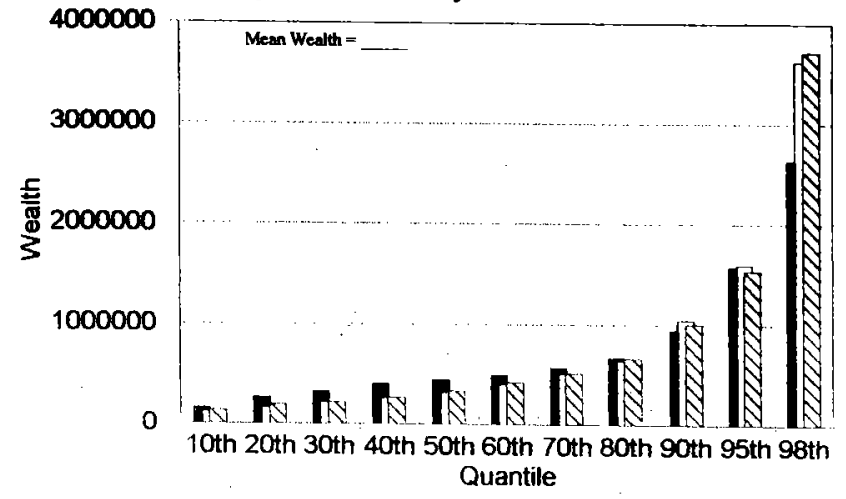

Investment Adjust | Unadjusted
Fig 4. 8th Income Decile Adjusted v Unadjusted Wealth Quantiles

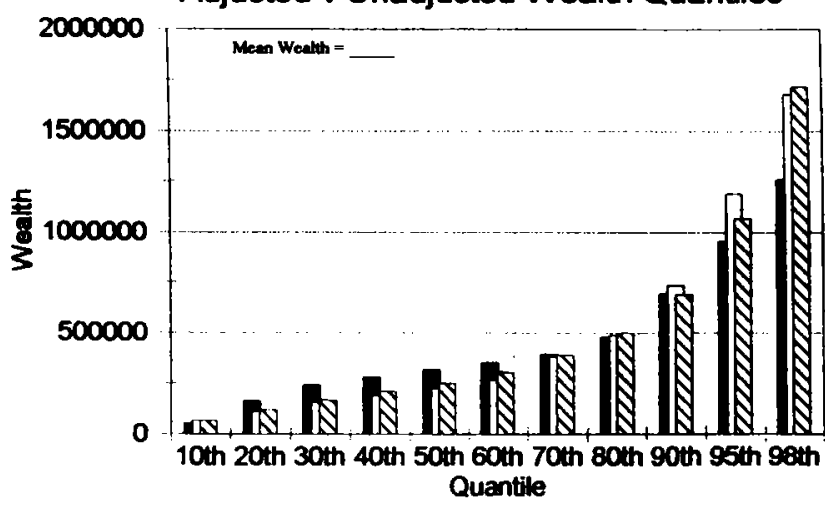

Investment Adjust $\square$ Unadjusted Chance Var Adjust

Fig 4. 10th Income Decile Adjusted v Unadjusted Wealth Quantiles

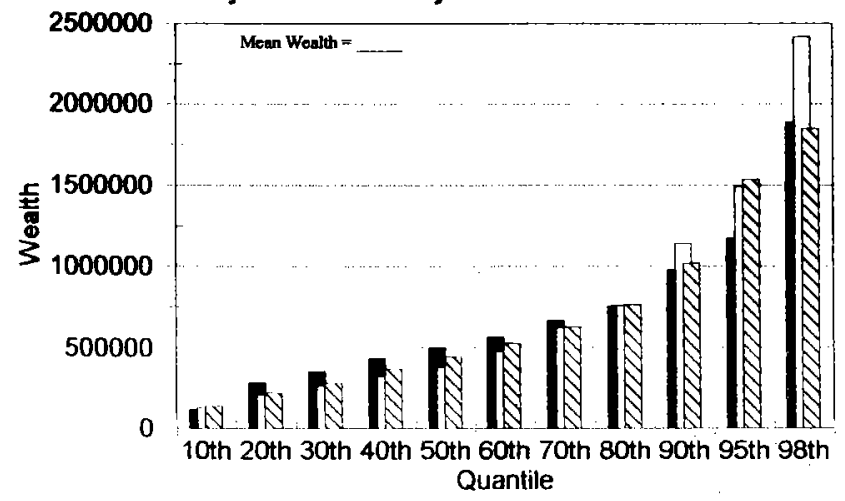

Investment Adjust | Unadjusted Ny Chance Var Adjust 


\title{
Fig 5. 7th Income Decile
}

\section{Adjusted v Unadjusted Wealth Quantiles}

2000000

\author{
Mean Wealth $=$
}

1500000

Invest Adjust

Unaadjusted

Chance Adjust

Incl Taste

$\sum^{\frac{5}{\mathbb{N}}} 1000000$

500000

0 10th 20th 30th 40th 50th 60th 70th 80th 90th 95th 98th Quantile 


\section{Fig 6. 7th Income Decile}

\section{Adjusted v Unadjusted Wealth Quantiles}

700000

600000

Mean IRA and Personal

Financial Assets $=$

500000

400000

$\stackrel{5}{\mathbb{d}} 300000$
$\stackrel{2}{3} 200000$

100000

$-100000$

10th 20th 30th 40th 50th 60th 70th 80th 90th 95th 98th Quantile 